\title{
IIIISGUCDERGI.ORG
}

"İȘ, GÜC̣" ENDÜSTRi ilLișKiLERI VE INSAN KAYNAKLARI DERGISi

"IS, GUC" INDUSTRIAL RELATIONS AND HUMAN RESOURCES JOURNAL

\section{Hizmet Sektöründe Çalışan Yoksulların Geçim Stratejileri ve Sosyal İlişki Ağları: Eskişehir Örneği}

\author{
Survival Strategies and Social Networks of The \\ Working Poor in The Service Sector: \\ The Case Of Eskişehir
}

\author{
Prof. Dr. Nadir Suğur* \\ Doç. Dr. Serap Suğur* \\ Öğr. Gör. Temmuz Gönç-Şavran* \\ Yrd. Doç. Dr. Oya Beklan Çetin* \\ *Anadolu Üniversitesi, Sosyoloji Bölümü Öğretim Üyesi
}

Ocak/Jaunary 2010, Cilt/Vol: 12, Say1/Num: 1, Page: 59-84 ISSN: 1303-2860, DOI: 10.4026/1303-2860.2010.138.x

Makalenin on-line kopyasına erişmek için:

http://www.isgucdergi.org/?p=makale\&id=391\&cilt=12\&sayi=1\&yil=2010

To reach the on-line copy of article:

http://www.isguc.org/?p=article\&id=391\&vol=12\&num=1\&year=2010

Makale İçin İletişim/Correspondence to: 
(C) 2000- 2010

"İşGüç" Endüstri İlişkileri ve İnsan Kaynakları Dergisi

"İşGüç" Industrial Relations and Human Resources Journal

Ocak/Jaunary 2010, Cilt/Vol: 12, Say1/Num: 1

ISSN: 1303-2860, DOI: 10.4026/1303-2860.2010.138.x

Editör/Editor-in-Chief

Aşkm Keser (Kocaeli University)

Editör Yardımcıları/Co-Editors

K.Ahmet Sevimli (Uludă̆ University)

Gözde Yılmaz (Kocaeli University)

Uygulama/Design

Yusuf Budak (Kocaeli Universtiy)

\author{
Yayin Kurulu / Publishing Committee \\ Dr.Zerrin Firat (Uludăg University) \\ Doç.Dr.Aşkın Keser (Kocaeli University) \\ Prof.Dr.Ahmet Selamoğlu (Kocaeli University) \\ Yrd.Doç.Dr.Ahmet Sevimli (Uludağ University) \\ Yrd.Doç.Dr.Abdulkadir Şenkal (Kocaeli University) \\ Yrd.Doç.Dr.Gözde Yilmaz (Kocaeli University) \\ Dr.Memet Zencirkıran (Uludă̆ University)
}

Uluslararası Danışma Kurulu / International Advisory Board

Prof.Dr.Ronald Burke (York University-Kanada)

Assoc.Prof.Dr.Glenn Dawes (James Cook University-Avustralya)

Prof.Dr.Jan Dul (Erasmus University-Hollanda)

Prof.Dr.Alev Efendioğlu (University of San Francisco-ABD)

Prof.Dr.Adrian Furnham (University College London-İngiltere)

Prof.Dr.Alan Geare (University of Otago- Yeni Zellanda)

Prof.Dr. Ricky Griffin (TAMU-Texas AEM University-ABD)

Assoc. Prof. Dr. Diana Lipinskiene (Kaunos University-Litvanya)

Prof.Dr.George Manning (Northern Kentucky University-ABD)

Prof. Dr. William (L.) Murray (University of San Francisco-ABD)

Prof.Dr.Mustafa Özbilgin (University of East Anglia-UK)

Assoc. Prof. Owen Stanley (James Cook University-Avustralya)

Prof.Dr.Işık Urla Zeytinoğlu (McMaster University-Kanada)

Danışma Kurulu / National Advisory Board

Prof.Dr.Yusuf Alper (Uludağ University)

Prof.Dr.Veysel Bozkurt (Uludağ University)

Prof.Dr.Toker Dereli (Işık University)

Prof.Dr.Nihat Erdoğmuş (Kocaeli University)

Prof.Dr.Ahmet Makal (Ankara University)

Prof.Dr.Ahmet Selamoğlu (Kocaeli University)

Prof.Dr.Nadir Suğur (Anadolu University)

Prof.Dr.Nursel Telman (Maltepe University)

Prof.Dr.Cavide Uyargil (İstanbul University)

Prof.Dr.Engin Yildırım (Sakarya University)

Doç.Dr.Arzu Wasti (Sabancı University)

Dergide yayınlanan yazılardaki görüşler ve bu konudaki sorumluluk yazarlarma aittir.

Yayınlanan eserlerde yer alan tüm içerik kaynak gösterilmeden kullanılamaz.

All the opinions written in articles are under responsibilities of the outhors.

None of the contents published can't be used without being cited. 


\title{
Hizmet Sektöründe Çalışan Yoksulların Geçim Stratejileri ve Sosyal İlişki Ağları: Eskişehir Örneği ${ }^{1}$
}

\author{
Survival Strategies and Social Networks of The Working Poor \\ in The Service Sector: The Case Of Eskişehir
}

\author{
Prof. Dr. Nadir Suğur* \\ Doç. Dr. Serap Suğur* \\ Öğr. Gör. Temmuz Gönç-Şavran* \\ Yrd. Doç. Dr. Oya Beklan Çetin*
}

*Anadolu Üniversitesi, Sosyoloji Bölümü Öğretim Üyesi

\begin{abstract}
Özet:
Çalışan yoksullarm düşük ücret ve yetersiz iş güvencesi nedeniyle sosyal ve ekonomik açıdan ne tür geçim stratejileri geliştirdikleri, yoksulluk literatürde sıkça tartışılmaktadır. Bu çalışma uygulamalı bir araştırmanın verilerinden yola çıkarak gündelikçileri, bakıcıları, apartman kapıcıların ve ücretli taksi şoförlerini ele almakta ve bu bağlamda çalışan yoksulların kente tutunabilmek için ne tür gelir arttırıcı ve gider azaltıcı stratejiler geliştirdiklerini irdelemektedir. Ayrıca bu çalışmada çalışan yoksulların kente tutunmalarında önemli bir rol oynayan sosyal ilişki ağlarının etkisi ve gücü sosyal sermaye kavramı bağlamında çözümlenmektedir.
\end{abstract}

Anahtar kelimeler: yoksulluk, çalışan yoksullar, sosyal sermaye, geçim stratejileri.

\begin{abstract}
:
There have been ongoing debates in the literature on the poverty of the working poor and their survival strategies to make ends meet. Based on fieldwork conducted on daily paid house cleaners, baby sitters, apartment door keepers and taxi drivers, this study looks at the ways in which the working poor develop maximizing income and minimizing expenses strategies for their own survival. Furthermore, this study also explores availability of social ties and networks conceptualized as social capital and their roles for the working poor to cope with the deprivations of poverty.
\end{abstract}

Key words: Poverty, working poor, social capital, survival strategies.

1 Bu çalışma Türkiye Bilimsel ve Teknik Araştırma Kurumu (TÜBİTAK) tarafindan SOBAG106-K012 no'lu proje kapsaminda desteklenmiştir. 


\section{Gíriş}

Yoksulluk, genel olarak temel bir gelirden yoksun olma anlamına gelmekle birlikte günümüzde başta eğitim, sağlık, istihdam ve sosyal güvence olmak üzere insanca yaşamak için gerekli olan insani gereksinimlerden ve kapasiteden yoksun olma anlamina gelen çok yönlü ve çok boyutlu bir içerik kazanmıştır. Nitekim küreselleşme ve liberalleşme ile birlikte yoksullukta azalma olmadığı gibi, günümüzde yeni yoksulluk biçimlerinin de ortaya çıktığ 1 artık hemen herkes tarafından kabul görmektedir. Son dönemlerde yoksulluk biçimlerinden en çok ilgi görenlerden biri de "çalışan yoksullar" olgusudur.

İstihdam ve yoksulluk kavramları görünüşte farklı kavramlar olmakla birlikte, özünde birbirlerini tamamlayan sosyal ve ekonomik eşitsizliklerin ayrılmaz birer parçasıdırlar. Bazı durumlarda istihdamın yapısı ve niteliği, eşitsizliği ve yoksulluğu yeniden üreten bir mekanizma haline gelebilmektedir. Küresel piyasa ekonomisine bağlı olarak değişen istihdam yapısı ile yoksulluğun yeni boyutlarından çalışan yoksullar arasında benzer bir ilişki bulunmaktadır. Nitekim yapılan çalışmalar küreselleşmenin bir taraftan formel ekonomide daralmaya, öte taraftan ise düşük ücretli, düzensiz, örgütsüz ve güvencesiz istihdamın yaygın olduğu enformel ekonomide genişlemeye yol açtığını göstermektedir (Chen, vd., 2005: 6). Bu da beraberinde yoksulluğun yeni bir boyutu olarak nitelenen çalışan yoksulları getirmiştir.

Çalışan yoksullar sorunu küresel bir olgu olmakla birlikte, özellikle az gelişmiş ülkelerde daha yaygın olarak karşımıza çıkmaktadır. Örneğin, Uluslararası Çalışma Örgütü'nün (ILO) 2006 yılı istihdam verilerine göre çoğunluğu az gelişmiş ülkelerde olmak üzere dünya ölçeğinde işsiz sayısı 200 milyona yaklaşmaktadır (ILO, 2007: 1-2). ILO'nun aynı çalışmasında istihdam edildiğ $i$ halde günlük geliri 2 dolar ve daha az olan çalışan yoksulların sayısının ise 1,37 milyara ulaştı̆̆ 1 belirtilmektedir (ILO, 2007). Bu nedenle, günümüzde ücretli çalışan işgücünün önemli bir bölümünü oluşturan ancak sos- yal ve ekonomik açıdan yoksulluk sınırının altında yaşayan "çalışan yoksullar" sorunu, yoksulluk tartışmaları içerisinde önemli bir yere sahiptir.

Çalışan yoksulların önemli bir bölümünü kadınlar oluşturmaktadır. Kadınların işgücü piyasalarında genellikle beceri gerektirmeyen, düşük ücretli ve sosyal güvenceden yoksun işlerde istihdam edildikleri birçok çalışmada belirtilmektedir (Ecevit, 2000; Scott, 1994; Ross ve Gatta, 1999; Munck, 2002; Bradshaw vd., 2003; Bora, 2005; Özyeğin, 2005; Chen, vd., 2005; Erdut, 2005). Birçok işkolunda kadınların, erkeklerle aynı işi yapmalarına rağmen erkeklerden daha düşük ücret aldıkları bilinmektedir (Cooper ve Lewis, 1999; Suğur, 2005; Erdut, 2005). Bu süreç kadının yoksullaşması ya da yoksulluğun kadınlaşması olarak da tanımlanmaktadir (Pearce, 1978; Segal, 1991:454, Payne, 1991; Rea, 1996; Sallangül 2005).

Kadın ya da erkek olsun çalışan yoksulların varlığ 21 . yüzyılda yoksullukla mücadelede alınan yolu, ayrıca modern küresel ekonomide istihdam yapisinin bireyleri yoksulluktan ne ölçüde koruduğunu göstermesi bakımından önem taşımaktadır. Nitekim adından da anlaşıldı ̆̆ı gibi, çalışan yoksulların yoksullukları istihdam dıșında olmalarından kaynaklanmamaktadır. Aksine çalışan yoksullar istihdam içinde ve bir gelir sahibidirler. Ancak buna rağmen yoksuldurlar. Yoksuldurlar çünkü insanca yaşayabilmeleri için yeterli düzeyde gelir getirici bir işe ve is güvencesine sahip değillerdir. Çalışan yoksulların çok defa düşük bir eğitim düzeyine ve işgücü niteliğine sahip olmaları da geliri ve güvencesi daha yüksek olan bir is edinme ve yoksulluktan kurtulma kapasitelerini de büyük ölçüde sınırlamaktadır. Bu nedenle çalışan yoksullar mevcut kapasitelerini yoksulluktan kurtulmak yerine ancak daha derin yoksulluğa düşmemek için belirli geçim stratejileri geliştirmeye yönelik olarak kullanabilmektedirler.

Dünya genelinde çalışan yoksulların istihdam içindeki payının artması son zamanlarda yoksullukla mücadelenin pek çok kurum ve kuruluşun gündeminde başlarda 
yer almasına yol açmıştır. Yoksullukla mücadele konusunda literatürde oldukça yoğun olarak tartışılan pek çok yöntem ve stratejiden söz edilmektedir. Bununla birlikte yoksullukla mücadeleye karşı yoksulların kendileri tarafından geliştirilen ve ilgili literatürde tartışılan çok çeşitli geçim stratejileri de söz konusudur.

Son dönemlerde yoksullukla mücadele stratejileri ile ilgili tartışmalara "sosyal sermaye" kavramı da eklenmiştir. Etkinlik ve verimliliğin artırılmasında sosyal bağ ve ağların, normların ve karşılıklı güvenin kullanımına işaret eden sosyal sermaye yoksullukla mücadelenin yeni stratejilerinden biri olarak, başta Dünya Bankası olmak üzere, belirli uluslararası kuruluşların yoksullukla mücadele çalışmaları kapsamına girmiştir.

$\mathrm{Bu}$ çalışmanın amacı Eskişehir örneğinden yola çıkarak hizmet sektöründe oldukça yaygın olan belirli mesleki kategorilerde çalışan yoksulları ve bu bağlamda istihdamyoksulluk ilişkisini uygulamalı bir araştırmanın verileri çerçevesinde sosyolojik olarak irdelemektir. Araştırmada hizmet sektöründe gündelikçilik, bakıcılık, kapıcılık ve ücretli taksi şoförlüğü mesleklerinde çalıştıkları halde yoksulluktan kurtulamayan önemli bir kesimin yoksullukla mücadelede sosyal ve ekonomik açıdan ne tür geçim stratejileri geliştirdikleri, özellikle son dönemlerde yoksullukla mücadelede önemli bir kavram ve yöntem olarak öne sürülen sosyal sermaye bağlamında, sosyolojik olarak irdelenmektedir.

\section{2. ÇALIŞAN YOKSULLARA YÖNELİK KURAMSAL TARTIŞMALAR}

Yoksulluğun günümüzde yalnızca istihdam dışında kalanları değil, istihdam edilenlerin önemli bir kesimini de etkilemesi, literatürde çalışan yoksullar olgusunun yoğun şekilde tartışılmaya başlamasına yol açmıştır (Newman, 2000; Ehrenreich, 2002; Shipler, 2005). Çalışan yoksulların tanımı konusunda farklı görüşler olsa da, konuyla ilişkili olarak yapılan çalışmaların büyük çoğunluğu, insanların çalıştıkları halde neden yoksul kaldıklarının nedenlerini açıklamaya çalışmaktadırlar.

Schiller (1994) ve Murray (1997) gibi bazı araştırmacılar çalışan yoksulların yeterince uzun saatler çalışmadıkları için yoksul olduklarını düşünmektedirler (Kim, 1998:1). Başka araştırmacılar ise (Danzinger ve Gottschalk, 1986; Bane ve Ellwood, 1991) çalışan yoksulların aynı ücretle çok daha uzun bir süre çalışmaya devam etseler bile yine de yoksulluktan kurtulamayacaklarını savunmaktadirlar (Kim, 1998:1-2; Chen, 2005:2). Bununla birlikte, çalışan yoksulların yoksulluklarının nedeninin büyük ölçüde işgücü piyasalarındaki olumsuz koşullardan kaynaklandığını öne süren çeşitli çalışmalar bulunmaktadır (Tobin, 1994; Jencks, 1996; Ross, Scott ve Smith, 2000; Quigley, 2003; ILO, 2007).

Shipler (2005) ise yoksulluğun karmaşık şekilde iç içe geçmiş hem bireysel hem de yapısal ekonomik nedenlerden kaynakladığını vurgular. Öte yandan başka bir araştırmada ise, bir işçinin yoksulluğunun kişisel nitelikler ya da piyasa koşullarıyla ilgili olmayabileceği, ailesinin ekonomik statüsünün bir sonucu olabileceği de ileri sürülmüştür (Chen, 2005:2).

Yoksulluk görünenden çok daha karmaşık bir olgu olsa da literatürde yoksulluğun nedenlerine yönelik tartışmalarda bireysel nedenlerden daha çok küreselleşme, liberalleşme, özelleştirme ve esnek istihdam gibi yapısal faktörlere vurgu yapılmaktadır (Şenses, 2001; Buğra ve Keyder, 2003, 2006; Chen, vd., 2005). İşgücü piyasasının istikrarsızlaşması, istihdamda sosyal güvencenin azalması, çalışmanın ve çalışma sürelerinin düzensizleşmesi, enformel istihdamin genişlemesi, sosyal refah rejimine yönelik baskıların oluşması ve benzeri gelişmeler çalışan yoksulların ortaya çıkmasına yol açan önemli etkenler arasında sayılmaktadır.

Düzenli bir işin ve yeterli bir gelirin yanı sıra çalışan yoksullar genellikle eğitim ve işgücü niteliği bakımından da düşük bir donanıma sahiptirler. Bu da, yoksulluğu salt gelir eksikliğinden çok yeterlilik/kapasite eksikliği 
açısından ele alan Sen'in yaklaşımıyla (Sen, 2004), çalışan yoksulların yoksulluktan kurtulma anlaminda yapabilirlik kapasitelerini oldukça sınırlamaktadır. Sen'in, Birleşmiş Milletler Kalkınma Programı (UNDP) İnsani Gelişme Endeksi tarafından da temel alınan insan yeterlilikleri yaklaşımına göre çalışan yoksulların yoksulluklarının temel nedeni gelir yoksulluğunun ötesinde onları yoksulluktan kurtaracak insani kapasitelerinin gelişiminin önündeki her türlü engel olarak görünmektedir (Sen, 2004). Örneğin, bu yaklaşıma göre eğitim, gelir açısından yoksul olsalar dahi, bireylerin yoksulluktan kurtulma kapasitelerini arttırır (Sen, 2004:131). Bu nedenle, bu yaklaşım açısından bakıldığında, bireylerin eğitimsel bir donanıma sahip olmaları aynı zamanda yoksulluktan kurtulmak için gerekli olan insani kapasitelerinin de gelişmesi anlamına gelmektedir.

Türkiye'de çalıştığı halde yoksul olanları tanımlamada "çalışan yoksullar" kavramı çok sık kullanılmasa da, özellikle göç ve enformel istihdam gibi ilişkili kavramlar bağlamında, çalışan yoksullara yönelik belirli bir literatür oluşmuştur. Bu bakımdan Türkiye'de göç ve enformel istihdam ile ilgili literatürün genel olarak yoksulluk çalışmalarına katkısı çok büyük olmuştur. Nitekim pek çok araştırmada Türkiye'de kırdan kente göç olgusu kentsel yoksulluğun temel nedenlerinden biri olarak ön plana çıkmış, enformel sektör ise kırdan kente gelen ve iş bulamayan yeni göçmenlere düşük ücretli, düzensiz, istikrarsız ve güvencesiz de olsa iş bulma imkanı sağlayan ve böylece derin yoksulluk içine düşmelerini bir ölçüde engelleyen bir sektör olarak nitelenmiştir (Özsoylu, 1994; Işık ve Pınarcıŏ̆lu, 2001;Buğra ve Keyder, 2003; Adaman ve Keyder, 2005; Erdut, 2007).

Türkiye'de enformel sektör istihdaminin yaygın olduğu bilinmekle birlikte bu istihdamın boyutlarını, özü itibarıyla düzenlenmemiş/kayıt dışı olması nedeniyle, kesin olarak belirlemek mümkün değildir. Bununla birlikte resmi istatistiklere göre Türkiye'de çalışan bireylerin işteki durumları itibariyle yoksulluk oranlarına bakıldığında; ücretsiz aile işçilerinden sonra yoksulluk oranının en yüksek olduğu grubun yevmiyeli çalışan işçiler olduğu ve yevmiyeli çalışan işçilerin de yoksulluk oranının \%31,12 olduğu belirtilmektedir (TÜIK, 2007). Son dönemde yapılan bir çalıșmada minimum gıda harcaması maliyeti yöntemine göre, Türkiye'de çalışan yoksulların oranının \% 53.67 olduğu öne sürülmektedir (Erdoğan, 2002). Başka bir çalışmada da Türkiye'de istihdam edilmiş nüfusun \%23'ünün yoksulluk riski altında olduğu ve bu rakamın, Avrupa Birliği ortalamasının üç katı olduğu belirtilmektedir (Adaman ve Keyder, 2005:vii).

Literatürde yer alan çalışmaların bir bölümünde, kırdan kente göçün yoğun olması, göç edenlerin vasıf ve eğitim düzeyinin düşük olması, yüksek işsizlik oranının ve formel sektördeki iş olanaklarının yetersiz olması gibi nedenler, bireyleri zorunlu olarak enformel sektörde istihdam arayışına yönelten nedenler olarak öne sürülmüştür (Özsoylu, 1994; Işık ve Pınarcığlu, 2001; Adaman ve Keyder, 2005). Bu araştırmaların sonuçları Türkiye'de enformel sektörde ücretli olarak çalıșan göçmenlerin kentin çalışan yoksullarının önemli bir bölümünü oluşturduğunu ortaya koymaktadır. Yalnızca Türkiye'de değil, dünya ölçeğinde çalışan yoksulların en çok yoğunlaştığ 1 alanlardan biri olarak bilinen enformel istihdama yönelik ilgi bu nedenle son dönemlerde giderek artmıştır (ILO, 2002; Chen, vd., 2005).

Yine Türkiye'de kırdan kente göçle gelen ailelerin kente genellikle enformel konut ve işgücü piyasası üzerinden eklemlenmeye çalıştıkları, sosyal ilişkiler söz konusu olduğunda da kente tutunmalarına destek olması açısından kente taşıdıkları akrabalık ve hemşehrilik bağlarını kullandıkları bu güne kadar yapılan çeşitli araştırmalar tarafından ortaya konulmuştur (Kıray, 1985; Erder, 1996; Iş1k ve Pınarcıoğlu, 2001; Buğra ve Keyder, 2003; Adaman ve Keyder, 2006; Kalaycıŏlu 2006). Geleneksel dayanışma ve yardımlaşma ağlarına ilişkin kimi çalışmalarda da (Ayata 1989) yoksullukla mücadele araçları olarak bu kavramların önemine değinilmiştir. Bu çalışmalardan Işık ve Pınarc1- 
oğlu tarafından (2001) yapılan çalışmada Türkiye'de kırdan kente göç edenlerin enformel konut ve işgücü piyasasını kullanarak kente tutunmayı başardıkları ve zamanla yoksulluklarını sonra gelenlere devrettikleri vurgulanmaktadır. Nöbetleşe yoksulluk olarak tanımlanan bu devredilebilir nitelikteki yoksulluk özellikle enformel sektörde çalışan yoksulların cemaat ilişkileri sayesinde kente tutunmada geliştirdikleri bir yoksulluk stratejisi olarak nitelenmektedir (Işık ve Pınarcıoğlu, 2001:77). Ancak aynı çalışmada Türkiye kentlerinde özellikle 1990'larla birlikte kentlerde enformel konut yapımına imkan tanıyan koşulların ortadan kalkması gibi çeşitli gelişmelerin göçle gelen nüfusun bugüne kadar kente tutunmasını sağlayan koşulları sekteye uğrattığı, bunun da göçmen ailelerin kente tutunmalarında önem taşıyan dayanışma ağlarında zayıflamaya yol açtığı vurgulanmaktadır (Işık ve Pinarcioğlu, 2001).

Buğra ve Keyder tarafından 2003 yılında yapılan çalışmada da nöbetleșe yoksulluk olarak tanimlanan olgunun 1980 sonrasinda geleneksel dayanışma ağlarının zayıflaması, toplumsal dişlanma ve marjinalleşmenin ise artması ile birlikte geçerliliğini yitirdiği, bunun yerine günümüzde geleneksel dayanışma ağları aracılığıyla iyileștirilemez düzeyde, başkalarına da devredilemeyen kalıcı nitelikte "yeni" bir yoksulluğun ortaya çıktığ1 savunulmaktadır (Buğra ve Keyder, 2003:18-19). Adaman ve Keyder tarafindan yapılan çalışmada da (2006) Türkiye'de, özellikle yoksulluk riskine karşı önemli bir destek mekanizması olarak işlev gören geleneksel dayanışma ağlarının son dönemlerde zayıfladığ 1 vurgulanmaktadır. Bu çalışmada özellikle "gecekondu" olarak bilinen olgudaki dönüşümle birlikte kentlere yeni gelen göçmenlerin gecekondularda kiracı olarak yaşamak durumunda kaldıkları ve hemşehrilik ilişkilerinden daha önce gelenler kadar yararlanamadıkları, bu nedenle de yoksulluğa düşmelerinin bir anlamda kaçınılmaz olduğu savunulmaktadır (Adaman ve Keyder, 2006). Geleneksel dayanışma ağlarının günümüzde etkinliğini yitirmekte olduğu başka çalışmalar tarafından da desteklen- mektedir (Wedel 2001; Kaşka vd. 2004; Erman, 2004)

Tüm bunlar Türkiye'de yoksullukla başa çıkmada önemli bir rolü olan geleneksel sosyal ağların görece önemini yitirdiğini göstermektedir. Yine de yukarıda belirtildiği gibi son zamanlarda Dünya Bankası (World Bank, 2000) gibi belirli kuruluşlar, sosyal ilişkiler ağına ait bir kavram olan sosyal sermayeyi yoksullukla mücadelede yeni bir strateji olarak öne sürmektedirler. Sosyal sermayeyi yükseltme aracılığıyla yoksullukla mücadele stratejisinin Dünya Bankası tarafından uzun zamandır savunulan devletin rolünün küçültülmesi ve kamu harcamalarının azaltılması yönündeki görüşle de uyum halinde olduğu vurgulanmaktadır (Øyen, 2002:12) Özellikle gelişmekte olan ülkelerde parasal sermayenin yokluğunda sosyal sermaye kavramının ekonomik kalkınmada ve yoksullukla mücadelede giderek daha çok önem kazandığı görülmektedir. Buna bağlı olarak da pek çok ülkede olduğu gibi Türkiye'de de sosyal sermayenin nasıl arttırılabileceğine yönelik araştırmalar yaygınlık kazanmaya başlamıştır (DPT, 2001; Aktan, 2002). Sosyal sermayenin güçlendirilmesi bir anlamda kaybolan sosyal bağ ve ağların, değerlerin ve karşılıklı güvenin yoksullukla mücadele bağlaminda yeniden tesis edilmesi anlamina gelmektedir.

İşte bu çalışmada çalışan yoksulların kente tutunmak amacıyla geliştirdikleri geçim stratejileri ve sosyal ilişki ağları son dönemlerde giderek önem kazanan sosyal sermaye kavramı çerçevesinde değerlendirilmeye çalışılmaktadır. Ancak buna geçmeden önce sosyal sermaye kavramı ile ilişkili literatürde yer alan tartışmalara kısaca değinmek yerinde olacaktır.

\section{Sosyal Sermaye Kavramı}

Kabaca tanimlamak gerekirse sosyal sermaye toplumsal ilişki ağlarına işaret etmede kullanılan bir kavramdır. Bu ilişki ağlarının eşit veya benzer sosyal ve ekonomik statüdeki aktörler arasında yatay olarak kurulabileceği gibi farklı ve eşit olmayan sosyal ve ekonomik statüdeki aktörler arasında dikey 
olarak da kurulabileceği öne sürülmektedir. Literatürde toplumsal ilişkiler alanından "sermaye olarak söz ediliyor oluşu, bireylerin kendi çıkarlarını gerçekleștirmek üzere üyesi oldukları toplumsal ilişki ağlarını birer kaynak olarak kullanabilme özelliğine" bağlanmaktadır (Özuğurlu, 2006:191). Bu bakımdan sosyal sermayeden basitçe "mesele ne bildiğin değil, kimi tanıdığındır" şeklinde söz edilmesi bundan kaynaklanmaktadır. Ayrıca sosyal ağların güçlendirilmesinin bireyler arasında ortak çıkar ve normların gelişmesini sağlayacağı, bunun da toplumda güvenin yanı sıra kültür ile yaşam tarzındaki farklılıkların daha iyi anlaşılmasına katkıda bulunacağına inanılmaktadır (Øyen, 2002:11). Buna paralel olarak yapılan çalışmaların bir bölümü tarafından zengin sosyal ağlara sahip toplulukların yoksullukla başa çıkmada daha güçlü bir konumda oldukları da gösterilmektedir (Woolcock, 2002:24).

Sosyal sermaye kavramı, özellikle son dönemlerde, bireylerin toplumsal tabakalaşma piramidi içerisindeki sosyal hareketlilikleri üzerinde önemli bir rol oynadığ1 varsay1mıyla, sosyal bilimler literatüründe sıklıkla kullanılmaktadır. Ancak kavramın çok yönlü ve çok boyutlu olması çeşitli tanımlamaları da beraberinde getirmiştir. Örneğin Putnam, sosyal sermayenin bireylerarası karşılıklı sosyal ilişkiler ağında oluştuğunu öne sürmektedir. Buna göre sosyal ilişkiler ağ1 gönüllü, güven ve destek sağlayıcı ve de dayanışmacı bir öze sahiptir (Putnam, 2000:19). Coleman (1988:98) ise sosyal sermayeyi bireyler arası yapısal ilişkiler olarak tanımlamaktadır. Coleman'a göre bu yapısal ilişkiler süreklilik arz etmekte ve bireylerin sosyal ve ekonomik konumlarının belirlenmesinde son derece önemli bir rol oynamaktadır. Bu tanımlamalardan anlaşılacağ 1 gibi sosyal sermaye bireylerin içinde bulunduğu sosyal ilişkiler ağına ilişkin bir kavram olarak kullanılmaktadır. Bununla birlikte, sosyal sermaye kavramı kullanılmaya başlamadan önce de, bu kavramın içerik olarak sosyal bilimlerin farklı terminolojileri içinde yer aldığı görülebilir. Örneğin Karl Marks'daki 'sınıf dayanışmasi', Emile Durkheim'daki ‘toplumsal da- yanışma' ve Max Weber'deki 'statü grupları' aslında toplumsal grupların içinde bulunduğu sosyal ilişkiler ağının önemine ilişkin olarak kullanılan kavramlardır.

Fiziksel olmaması nedeniyle tanımlanması kolay olmasa da, kaynağının toplumsal ilişki ağları/bağları olması nedeniyle, sosyal sermayeye yoksulların erişilebilmesinin nispeten daha kolay olduğu varsayılmaktadır. Sosyal sermaye çok defa yoksulların sahip oldukları tek sermaye olarak da nitelenmektedir. Bu nedenle de son dönemlerde yoksulluk literatüründe sosyal sermaye kavramindan sıklıkla söz edilmektedir. Öyle ki iyi bir iş güvencesi sağlayabilecek belirli sosyal ağların dışında olmanın kendisi yoksul olmayı tanımlayan bir özellik olarak kabul görmektedir.

Ne var ki sosyal sermaye kavraminin yoksullukla ilgili literatürde yaygın olarak kullanılmaya başlaması bazı eleştirileri de beraberinde getirmiştir. Sosyal sermaye kavramını kullanan kimi sosyal bilimciler, toplumsal cinsiyet, eşitsizlik, çatışma ve sınıf gibi temel kavramları göz ardı ettikleri ve sosyal ilişkilere yalnızca işlevsel ve dayanışmacı özellikler açısından yaklaştıkları gerekçesiyle eleştirilmektedirler (Molyneux, 2002). Gerçekten de bazı çalışmalarda sosyal sermaye kavramı ile toplumcu dayanışma ruhunun fazlaca romantikleştirilmesi ve kavramın alt gelir grupları içindeki bireylerin devletten herhangi bir destek almadan da kendi başlarına var olabilecekleri şeklinde liberal bir teze dayalı olarak kullanılması oldukça sorunlu görünmektedir. Ayrıca belirli bir grubun güçlü sosyal ağlara veya sosyal sermayeye sahip olmasının başka bireylerin ve grupların dişlanmasına yol açacağı vurgulanmaktadır. Özellikle sınıf sisteminin olduğu bütün toplumlarda yoksul sinıfların yoksul olmaları nedeniyle zengin sinıflara benzer güçlü sosyal ağlara sahip olamadıkları ve çok defa zenginlerin sahip oldukları ağlardan dışlandıkları bilinmektedir. Bu bakımdan literatürde sosyal sermayenin olumlu özellikler kadar olumsuz özelliklere de sahip olduğunun altı çizilmektedir. 
Bu noktada sosyal sermaye kavramina ilişkin farklı bir bakış açısı getiren Pierre Bourdieu'nun çalışmaları önem arz etmektedir. Bourdieu sosyal sermayeyi, habitus kavramı bağlamında yeniden değerlendirdiği sosyal sınıf kavramı ve eșitsizlik ile ilişkilendirerek ele alır. Bu yaklaşımda Bourdieu bireylerin, özellikle belirli statülere ulaşma anlamında toplumsal konumlarının belirlenmesinde, ekonomik sermayenin yanı sıra kültürel sermaye ve sosyal sermaye olarak adlandırdığ iki farklı sermaye tipinin daha öneminden söz eder². Bourdieu'ya göre (1986), ekonomik ve kültürel sermayenin yanı sıra sosyal sermaye de bireylerin sosyal ve ekonomik kökenleri ve içinde bulundukları sosyal ve kültürel ortam ile yakından ilişkilidir. Sosyal ve ekonomik yaşamı bir spor müsabakasına benzeten Bourdieu, sosyal ve kültürel donanımlar açısından güçlü olanlar ile güçsüz olanların eşit olmayan bir mücadele içerisinde olduklarını öne sürmektedir. Çünkü ekonomik sermaye gibi sosyal ve kültürel sermaye de toplumda eşit dağıtılmamıştır. Buna göre, toplumsal tabakalaşma piramidinin tepe noktasından tabanına doğru inildikçe de, bireylerin etkili ve güçlü sosyal sermayeye sahip olabilme potansiyelleri azalmaktadır. Bu bakımdan bireylerin belirli statülere ulaşmada kullanabildikleri etkin ve güçlü toplumsal ağlar olarak sosyal sermaye, toplumsal eşitsizliklerin yeniden üretilmesinde bir kaynak olabilmektedir. Sosyal sermaye özellikle üst sinıflar tarafından s1nifsal ayricalıklarin korunmasında kullanılabilmektedir (Bourdieu, 1986).

Sonuç olarak sosyal sermaye kavramına yönelik farklı yaklaşımlar literatürde kavramın yoksullukla mücadelede ne ölçüde bir güce ve öneme sahip olduğu konusunda farklı görüşleri de beraberinde getirmiştir. Bu çalışmanın amacı ne sosyal sermaye kavramının ne de bu kavrama yönelik yaklaşımların eleştirel bir değerlemesini yapmak değildir. $\mathrm{Bu}$ çalışmanın amacı kentin çalışan yoksul- larının özellikle kentsel alanda geliştirdikleri sosyal ağların sosyal sermayelerini ne ölçüde yükselttiğini ve bunun da yaşam stratejilerini ve yukariya doğru toplumsal hareketliliklerini ne ölçüde etkilediğini Eskişehir örneğinde incelemektir. Çalışmada, özellikle Türkiye'de bu güne kadar sınırlı sayıda (Kalaycıoğlu ve Rittersberger-Tilıç, 2001; Özyeğin, 2005; Bora, 2005) araștırmanın yapıldığı hizmet sektöründe çalışan yoksulların sosyal ilișki ağlarını yoksullukla baș etmede ne ölçüde sosyal bir sermaye olarak kullandıkları incelenmektedir.

\section{ARAŞTIRMA YÖNTEMI}

Bu çalışmanın evrenini Eskişehir'de hizmet sektöründe istihdam edilen çalışan yoksullar oluşturmaktadır. Araştırmada çalışan yoksullar içerisinde yer alan dört meslek grubu ele alınmıştır. Bu bağlamda örneklem grubu apartman kapiciları, apartmanlarda temizliğe giden gündelikçi kadınlar, bakıc1lar ve maaşlı/ücretli olarak çalışan taksi şoförlerinden oluşturulmuştur. İstihdam süreçlerinin enformel, iş tanımlarının büyük ölçüde belirsiz ve ücretlerin de düşük olması, bu meslek gruplarının çalışan yoksulları temsil eden kategoriler olduğu düşüncesine yol açmış ve örnekleme bu nedenle dahil edilmişlerdir ${ }^{3}$. Nitekim aşağıda bulgular kısmında görüleceği üzere düşük eğitim düzeyi ve işgücü niteliğinin yanı sıra özellikle gelir, tüketim ve harcama gibi ölçütler aşısından bakıldığında da, bu mesleki kategorilerden örnekleme katılanların çoğunluğu büyük ölçüde yoksul olarak nitelenebilecek durumdadirlar. Öte yandan bu mesleki kategorilerin enformel bir istihdam sürecine sahip olmaları nedeniyle kayıtlı olmamaları, çalışanların sayısı gibi mesleklere ilişkin istatistiki verilere ulaşılmasını engellemiştir. Bununla birlikte, bu mesleki kategorilerde çalışan önemli bir işgücü olduğu ampirik olarak bilinmektedir. Buna dayanarak araştırma kapsamında hizmet sektö-

\footnotetext{
${ }^{2}$ Bourdieu bu üçlemeye daha sonra sembolik sermaye kavramını da eklemiştir.

${ }^{3}$ Her ne kadar bu dört meslek grubu içerisinde yer alan kapıcılar sözleşmeli çalışıyor olsalar da ücret düzeyleri, çalışma koşulları ve iş tanımlarımın belirsizliği, mesleği enformelleştirmektedir.
} 
ründe çalışan yoksulların ortak özelliklerini ortaya koyabilmek için seçilen bütün meslek gruplarından eşit sayıda kişi örnekleme dahil edilmiş ve her bir meslek grubundan 100 kişiyle yapılandırılmış görüşme yapılmasına karar verilmiştir. Sonuç olarak araştırma kapsaminda toplamda 400 kişiyle görüşme yapılmıştır. Ayrıca örneklem grubundan 19 kişiyle derinlemesine görüşmeler yapılmıştır. Araştırma 2006-2007 yılları arasinda yürütülmüştür.

Araştırmada örneklem grubunun sosyal, ekonomik ve demografik özellikleri (toplumsal cinsiyetleri, sinıfsal kökenleri, eğitim düzeyleri, gelir durumları v.b) ile yoksullukları ve yoksullukla baş etmede ne gibi gelir artıcı ve gider azaltıcı stratejiler geliştirdikleri çok yönlü olarak irdelenmeye çal1şılmıştır.

\section{Örneklem Grubunun Sosyal Profili}

Örneklem grubunu oluşturan 400 kişiden elde edilen verilere göre, cevaplayıcıların $\% 52$ 'si kadın, \%48'i erkektir. Yaklaşık üçte ikisi (\%73) 30-49 orta yaş grubunda yer alan cevaplayıcıların \%83'ü evlidir. Yarısından fazlası (\%69) ilkokul mezunu olan cevaplayıcıların baba mesleği incelendiğinde $\% 43$ 'ünün babasının çiftçi, \%38'inin ise babasının işçi ya da işçi emeklisi olduğu gözlenmiştir (bk. Tablo 1).

Cinsiyet dağılımı meslek gruplarına göre incelendiğinde, gündelikçilik ve bakıcılığın kadın işleri, kapıcılık ve taksi şoförlüğünün ise erkek işleri olarak kabul edilmesine rağmen, kapıcılık alanında kadınların da (\%10) bu mesleği tercih etmeye başladıkları gözlenmiştir (bk. Tablo 1)4. Bunun nedeni, mer-

Tablo 1

Sosyal ve Demografik Özellikler

\begin{tabular}{|c|c|c|c|c|c|}
\hline$\%$ & $\begin{array}{c}\text { Kapıc1 } \\
\text { n=100 }\end{array}$ & $\begin{array}{l}\text { Şoför } \\
n=100\end{array}$ & $\begin{array}{l}\text { Gündelikçi } \\
n=100\end{array}$ & $\begin{array}{c}\text { Bak1c1 } \\
n=100\end{array}$ & $\begin{array}{c}\text { Toplam } \\
n=400\end{array}$ \\
\hline $\begin{array}{c}\text { Cinsiyet } \\
\text { Kadın } \\
\text { Erkek }\end{array}$ & $\begin{array}{l}10 \\
90\end{array}$ & $\begin{array}{c}- \\
100\end{array}$ & $\begin{array}{c}100 \\
-\end{array}$ & $\begin{array}{c}100 \\
-\end{array}$ & $\begin{array}{l}52 \\
48\end{array}$ \\
\hline $\begin{array}{l}\text { Yaş } \\
29 \text { ve altı } \\
30-49 \\
50 \text { ve üzeri }\end{array}$ & $\begin{array}{c}3 \\
80 \\
17\end{array}$ & $\begin{array}{l}13 \\
56 \\
31\end{array}$ & $\begin{array}{c}6 \\
87 \\
7\end{array}$ & $\begin{array}{c}9 \\
70 \\
21\end{array}$ & $\begin{array}{c}8 \\
73 \\
19\end{array}$ \\
\hline $\begin{array}{l}\text { Baba Mesleği } \\
\text { İşçi/emekli işçi } \\
\text { Memur/emekli memur } \\
\text { Serbest meslek } \\
\text { Çiftçi-köylü }\end{array}$ & $\begin{array}{c}26 \\
1 \\
2 \\
71\end{array}$ & $\begin{array}{l}61 \\
10 \\
15 \\
14\end{array}$ & $\begin{array}{c}34 \\
5 \\
13 \\
48\end{array}$ & $\begin{array}{l}30 \\
12 \\
19 \\
39\end{array}$ & $\begin{array}{c}38 \\
7 \\
12 \\
43\end{array}$ \\
\hline $\begin{array}{l}\text { Medeni Durumu } \\
\text { Evli } \\
\text { Bekar } \\
\text { Boşanmış } \\
\text { Dul }\end{array}$ & $\begin{array}{c}94 \\
- \\
4 \\
2\end{array}$ & $\begin{array}{c}86 \\
10 \\
3 \\
1\end{array}$ & $\begin{array}{c}81 \\
2 \\
7 \\
10\end{array}$ & $\begin{array}{c}72 \\
6 \\
10 \\
12\end{array}$ & $\begin{array}{c}83 \\
5 \\
6 \\
6\end{array}$ \\
\hline $\begin{array}{l}\text { Eğitim Durumu } \\
\text { Diploması yok } \\
\text { Illkokul Mezunu } \\
\text { Ortaokul Mezunu } \\
\text { Lise Mezunu } \\
\text { Üniversite Mezunu }\end{array}$ & $\begin{array}{c}1 \\
71 \\
22 \\
6 \\
-\end{array}$ & $\begin{array}{c}1 \\
50 \\
14 \\
32 \\
3\end{array}$ & $\begin{array}{c}6 \\
84 \\
7 \\
3 \\
-\end{array}$ & $\begin{array}{c}7 \\
71 \\
10 \\
12 \\
-\end{array}$ & $\begin{array}{c}4 \\
69 \\
13 \\
13 \\
1\end{array}$ \\
\hline
\end{tabular}

4 Eskişehir'e doğalgaz 1996 yılında gelmiştir. 2007 yılı itibarıyla 570,000 kişinin yaşadı̆̆̆ Eskişehir kent merkezinde doğalgaz abone sayısı 210,000 civarmdadır. 
kezî 1sıtma sistemi bulunan binalarda yoğun bedensel güç, beceri ve de 'ateşçi' sertifikası gerektirmesi nedeniyle kullanımı kapıcılar açısından oldukça zahmetli olan kömür yerine, doğalgaz kullanımının giderek artan yoğunlukta tercih edilmesidir.

Doğum yerlerine ve göçmenlik durumlarına bakıldığında, aşağıda Tablo 2'de görüldüğü gibi, örneklemin yarıdan fazlası Eskişehir doğumlu ve yarısına yakını köy kökenlidir. Mesleklere göre doğum yerleri ve birim büyüklükleri karşılaştırıldığında, dört meslek grubu içinde şoförler büyük ölçüde Eskişehir' in yerlisi ve kent kökenli olmaları açısından, kapıcılar ise köy kökenli olmaları açısından diğer meslek gruplarından farkl1laşmaktadırlar (bk.Tablo 2).

Göç hareketleri incelendiğinde örneklemin yarısından fazlası Eskişehir il merkezine ortalama 18 yıl önce göç yoluyla gelmiştir. Mesleklere göre göç dağılımı incelendiğinde, göç oranının en yüksek olduğu grubun (\%89) kapıcılar, en düşük olduğu grubun ise (\%27) şoförler olduğu görülmüştür. Eskişehir merkeze göç ederek gelen kapıcıların ortalama 15 yıl, şoförlerin 28 yıl, gündelikçilerin 16 yıl ve bakıcıların da 20 yıl önce göç ettiği gözlenmiştir. Örneklemdekiler açısından köyden Eskişehir merkeze (\%48) ve başka şehirlerden Eskişehir merkeze (\%47) göçün neredeyse eşit ölçüde olduğu görülmüştür (bk. Tablo 2).

Araştırmada örnekleme girenlerin kırdan kente göç esnasında daha derin yoksulluğa düşmelerini önlemesi ve kente daha çabuk tutunmalarına destek olması açısından önem taşıyan hemşehrilik ağlarını kullanım oranlarının ise düşük olduğu görülmüştür. Nitekim örnekleme katılanların dörtte üçü (\%75) göç sırasında hemşehri, akraba ya da arkadaş yardımı almadığını belirtmiştir (bk. Tablo 2). Bu durum yukarıda adı geçen ve Türkiye'de 1980 öncesine oranla son dönemlerde kırdan kente gelen göçmenler arasında hemşehrilik ağları ve benzeri destek mekanizmalarının giderek azaldığ1 yönünde bir sonuca ulaşan çalışmaları (Işık ve Pınarc1oğlu, 2001; Buğra ve Keyder, 2003) destekler niteliktedir.
Göç sırasında hemşehri ve akraba yardımını \%30 ile en fazla alan grubun ise gündelikçiler olduğu görülmüştür. Genel olarak iş bulma, yatacak yer ve parasal destek sağlama şeklinde olan bu yardımların kente yeni göç edenlerin kente tutunabilmeleri aç1sından önemini bazı gündelikçi kadınlar aşağıdaki şekilde ifade etmişlerdir:

"Dört ay boş kaldiğım sürece işte să̆da, solda orda halamlar vardı onlar yardim ettiler. Ne bileyim arkadaşım yardım etti, evimin kirasımı falan onlar ödediler."

"3 aylığına kayınpederin evinde kaldık"

"Kayınpederimin evinde kaldim 5 sene"

"Babamın evine yerleşmek üzere geldim. Evinde barınmamı sağlıyor. Arkadaşlarım yardım ediyor borç paraya sıkıştığımda."

"Bu işi bulmamıza eşimin teyzesi yardımcı oldu. Teyzesi buraya temizliğe geliyodu, kapıcılarm çıkarmışlar işte, o da benim yeğenim var demiş"

"İşi falan ablam buldu. Öyle yardımı çok dokundu yani."

\section{"Kardeşim burada kapıcıdı, o getirdi bizi."}

Örneklem grubundaki dört meslek grubunun çalışma deneyimlerine bakıldığında önemli farklılıklar göze çarpmaktadır. Şu anda çalıștıkları işten önce başka bir iş deneyimine sahip olmayanların oranı gündelikçilerde $\% 45$ ve bakıcılarda $\% 48$ iken, bu oran kapıcılarda \%33'e, şoförlerde ise $\% 7^{\prime}$ ye gerilemektedir. Şu anki işlerinde çalışmaya başlamadan önce, kapıcılar ortalama 8 yıl, şoförler ortalama 15 yıl; gündelikçiler ortalama 5 yıl ve bakıcilar da ortalama 5 y1l başka işlerde çalışmışlardır. Daha önce başka işler yapanlar içinde en büyük grubu "işçilik" yapanlar oluşturmaktadır. Bakıcıların $\% 46$ 's1, şoförlerin $\% 40$ '1, gündelikçilerin \%37'si ve kapıcıların \%13'ü son beş yıl içinde işsiz kalmıştır. Son beş yıl içinde işsizlik deneyimi olan gündelikçiler ve şoförler ortalama 1 yıl işsiz kalırken bakıcılar 1,5 yıl ve kapıcılar da 2 yıl işsiz kalmıştır.

Son olarak çalışma saatlerine bakıldığında düzenli ve sürekli iş bulma konusunda s1kıntı çeken gündelikçiler hariç örneklemde- 
Tablo 2

Örneklemdekilerin Doğum Yerleri ve Göçmenlik Durumları

\begin{tabular}{|c|c|c|c|c|c|}
\hline$\%$ & $\begin{array}{c}\text { Kapic1 } \\
\mathrm{n}=100\end{array}$ & $\begin{array}{l}\text { Şoför } \\
n=100\end{array}$ & $\begin{array}{c}\text { Gündelikçi } \\
n=100\end{array}$ & $\begin{array}{l}\text { Bak1c1 } \\
n=100\end{array}$ & $\begin{array}{c}\text { Toplam } \\
n=400\end{array}$ \\
\hline $\begin{array}{l}\text { Doğduğu şehir } \\
\text { Eskişehir } \\
\text { Çevre iller } \\
\text { Diğer iller } \\
\text { Metropol } \\
\text { Yurtdışı }\end{array}$ & $\begin{array}{c}57 \\
31 \\
3 \\
3 \\
6\end{array}$ & $\begin{array}{c}87 \\
5 \\
6 \\
2 \\
-\end{array}$ & $\begin{array}{c}70 \\
20 \\
4 \\
5 \\
1\end{array}$ & $\begin{array}{c}59 \\
15 \\
14 \\
11 \\
1\end{array}$ & $\begin{array}{c}* 68 \\
18 \\
7 \\
5 \\
2\end{array}$ \\
\hline $\begin{array}{l}\text { Birim } \\
\text { Köy } \\
\text { Kasaba-ilçe } \\
\text { Şehir Merkezi }\end{array}$ & $\begin{array}{c}74 \\
18 \\
8\end{array}$ & $\begin{array}{l}10 \\
28 \\
62\end{array}$ & $\begin{array}{l}41 \\
30 \\
29\end{array}$ & $\begin{array}{l}41 \\
28 \\
31\end{array}$ & $\begin{array}{l}42 \\
26 \\
32\end{array}$ \\
\hline $\begin{array}{l}\text { Göç edip etmediği } \\
\text { Evet } \\
\text { Hayır }\end{array}$ & $\begin{array}{l}89 \\
11\end{array}$ & $\begin{array}{l}27 \\
73\end{array}$ & $\begin{array}{l}59 \\
41\end{array}$ & $\begin{array}{l}55 \\
45\end{array}$ & $\begin{array}{l}58 \\
42\end{array}$ \\
\hline $\begin{array}{l}\text { Nereden göç ettiği } \\
\text { Eskişehir'in köylerinden } \\
\text { Başka kentten } \\
\text { Yurtdışından }\end{array}$ & $\begin{array}{c}56 \\
37 \\
7\end{array}$ & $\begin{array}{c}48 \\
52 \\
-\end{array}$ & $\begin{array}{c}53 \\
44 \\
3\end{array}$ & $\begin{array}{c}29 \\
66 \\
5\end{array}$ & $\begin{array}{l}48 \\
* 47 \\
5\end{array}$ \\
\hline $\begin{array}{l}\text { Göç sırasında hemşehri, akraba ve } \\
\text { arkadaşlarından yardım alıp almadığı } \\
\text { Evet, aldım } \\
\text { Hayır, almadım }\end{array}$ & $\begin{array}{l}26 \\
74\end{array}$ & $\begin{array}{c}8 \\
92\end{array}$ & $\begin{array}{l}30 \\
70\end{array}$ & $\begin{array}{l}24 \\
76\end{array}$ & $\begin{array}{l}25 \\
75\end{array}$ \\
\hline
\end{tabular}

*Not: Tablo 2'de ikinci satırda örneklemin \%68'inin Eskişehir doğumlu olduğu verisi ile beşinci satırda örneklemin \%47'sinin başka kentlerden Eskişehir'e göç etmiş olduğu verisi ilk bakışta çelişkili gibi görünmektedir. Bu durum örneklem içinde bazı kişilerin Eskişehir'de doğduğu halde yaşamlarının bir aşamasında evlilik, iş ya da başka nedenlerle komşu illerin çeşitli ilçelerine göç etmiş ve daha sonra yeniden Eskişehir'e dönmüş olmalarından kaynaklanmaktadır.

kiler haftada en az 40 saat ve üzerinde çalışmaktadırlar. Bu veriler, çalışan yoksulların yeterince çalışmadıkları için yoksul oldukları yönündeki iddia ile uyuşmamaktadır.

Dört meslek grubundan örnekleme girenlerin sosyal ve demografik özelliklerine genel olarak bakıldığında beş ortak özelliğin ön plana çıktığ 1 görülmektedir. Bu ortak özellikler açısından örnekleme girenler aşağ1daki şekilde tanımlanabilir.

—Alt gelir grubundan gelmektedirler.

-Yarıya yakını kırsal kökenli olup kente sonradan göç etmişlerdir.
—Eğitim düzeyleri oldukça düşüktür. Örneklemin \%72'si ilkokul veya daha düşük bir eğitim düzeyine sahiptir.

-Taksi şoförlerinin ehliyet sahibi olmaları haricinde, örneklem grubundaki bireylerin vasıf düzeyi oldukça düşüktür.

-Büyük bir çoğunluğu görece genç sayılabilecek yaştadır (\%83'ü 50 yaşın altındadır).

—Genellikle evli ve çocukludurlar.

-Çalışma yaşamları boyunca tek ve sürekli bir işte tutunamamış, çeşitli işlerde çalışmış ve belirli dönemlerde işsiz kalmışlardır. 
Yukarıdaki özellikler Türkiye'de yoksulluğun ve yoksulluk riskinin kırsal kökenliler, göçmenler, düşük eğitim düzeyine sahip olanlar, enformel olarak istihdam edilenler ve şüphesiz asgari yaşam standardını karş1layacak yeterli düzeyde gelirden yoksun olanlar arasında daha yüksek olduğunu gösteren yoksulluk çalışmalarının sonuçları ile benzerlikler göstermektedir (Işık ve Pınarc1oğlu, 2001; Toksöz ve Özşuca, 2002; Lordoğlu, 2006; Erdoğan, 2007; TUİK, 2007). Demografik açıdan bu araştırmada göze çarpan tek farklılık ise, Tablo 2'de görüldüğü gibi, örneklem grubunda köylerden Eskişehir merkeze göç edenlerin oranının başka şehirlerden Eskişehir merkeze göç edenlerin oranı ile neredeyse eşit olmasıdır. Yoksullukla ilgili diğer çalışmalarda ise kent yoksulları arasında kente dişarıdan gelenlerin oranı genellikle daha yüksek olabilmektedir. Eskişehir'in büyük ölçekli bir kent olmaması, istihdam olanaklarının sınırlı olması ve kışın soğuk olması nedeniyle ısınma ve barınma maliyetlerinin görece yüksek olması diğer şehirlerden ve bölgelerden Eskişehir'e yönelik göçün görece sinırlı düzeyde olmasına yol açmaktadır. Ayrıca, Eskişehir'e yakın önemli bir sanayi merkezi olan Bursa'nın iç göç sürecinde daha cazip bir kent olması da başka şehirlerden Eskişehir'e göçün diğer büyük kentlere oranla daha sınırlı düzeyde gerçekleşmesine yol açmaktadır.

\section{YOKSULLUKLA BAŞ ETME STRATEJI- LERI}

Eskişehir'in diğer şehirlerden aldığı göç yüksek düzeyde olmasa da, köylerden Eskişehir merkeze gelen eğitimsiz ve vasıfsız göçmenlerin, özellikle son dönemlerde ekonomik krizlere bağlı olarak istihdam olanaklarında meydana gelen daralmanın da etkisiyle, iş bulabilmeleri ya da mevcut işlerinde tutunabilmeleri nispeten zorlaşmaktadır. Ancak kent yoksulları, işgücü piyasasında artan rekabet ortamına paralel olarak farklı geçim stratejileri geliştirebilmektedirler. Bu stratejilerin iki farklı dinamikten beslendiği söylenebilir. Bunlardan birincisi sosyal sermaye, ikincisi ise hane düzeyindeki geçim stratejileridir. Bu iki temel geçim stratejisini araştırmanın verileri çerçevesinde kısaca ele almaya çalışalım.

\section{Bir Geçim Stratejisi Olarak Sosyal Sermaye}

Sosyal sermaye ile ilgili öne sürülen ve yukarıda özetlenen tezleri araştırmanın temel verileri çerçevesinde değerlendirecek olursak, örneklem grubunun sosyal sermayesinin son derece yetersiz olduğu söylenebilir. Zira eğitimsizlik, vasıfsızlık, kırsal kesimden göç etmiş olma ve enformel olan bir işgücü piyasası aracılığıyla var olmaya çalışma gibi özellikler, örneklem grubunun çok büyük oranda önemli ve güçlü sosyal ilişkiler ağ1nın dişında kaldığının göstergeleridir. Burada önemli ve güçlü sosyal ilişkiler ağı ile kastedilen, enformel sektörde bulunan bireylerin formel sektöre geçişlerini mümkün kılabilecek önemli ve etkili kişilerle ve kurumlarla olan doğrudan ve/ya dolaylı ilişkilerinin hazırda ve kullanılabilir olma durumudur. Örneklemi oluşturan dört meslek grubunda yer alanların tamami enformel istihdam koşulları altında, düşük ücretli ve sosyal güvencesi yetersiz işlerde çalışmaktadir.

Formel sektöre geçişi mümkün kılacak etkili ve güçlü sosyal ilişkiler ağından yoksun olma durumu, örneklem grubundaki çalışan yoksulları ister istemez benzer sosyal ve ekonomik konumda bulunan diğer bireylerle yatay dayanışma ilişkilerine zorlamaktadır. $\mathrm{Bu}$ açıdan bakıldığında bu araştırmada örnekleme girenler tarafından kentlerde kurulan arkadaşlık ve komşuluk ilişkilerine dayanan ve hemşerilik ağının yerini önemli ölçüde alan yeni bir sosyal ilişkiler ağ oluşturulduğu görülmüştür. Özellikle iş bulma konusunda dört meslek grubundan örnekleme girenlerin \%59'unun kentlerde kurulan bu yeni arkadaşlık ve komşuluk ilişkilerini kullandığ1 gözlenmiştir.

Sosyal sermayenin yatay kullanımının, örneklem grubundaki dört meslek grubunun enformel sektör içerisinde tutunmasını sağladığ1 söylenebilir. Bununla birlikte alt gelir gruplarının sahip olduğu sosyal ilişkiler ağ görece güçsüz ve etkisiz olduğu için çalışan yoksulları formel sektöre taşımada son de- 
rece yetersiz kalmaktadır. Örneğin taksi şoförlerinin sosyal çevresi çok büyük oranda yine düşük ücretle çalışmak durumunda olan şoförlerden oluşmaktadır. Bu çevre içerisinde genellikle ücretli taksi şoförleri, dolmuş şoförleri, kamyon şoförleri ve çeşitli kuruluşların araçlarında düşük ücretli olarak çalışan ticari araç şoförleri bulunmaktadır. Taksi şoförlerinin sahip olduğu bu tür bir çevrede sosyal sermaye yatay olarak kullanılmaktadır. Bu yataylık benzer işlere girip çıkan, ancak ekonomik yönden formel sektöre eklemlenemeyen bir meslek yapısını ortaya çıkarmaktadır. Çok sayıda ehliyetli kișinin kentsel işgücü piyasasına girmesi, "ehliyetli olma vasfını" değersizleștirerek bir "vasıf" olmaktan çıkarmaktadır. Vasıfsızlaştırma (Braverman, 1974) olarak tanımlanabilecek olan bu süreç şoförlerin, başta ücret düzeyleri olmak üzere, çalışma koșullarını hızla enformelleştirmektedir. Kaldı ki, mesleki yapı açısından bakıldı ̆̆ında, ücretli taksi şoförlüğü ile elde edilen gelirle, şoförlerin ticari taksi hattı sahibi olabilmeleri mümkün değildir. Çünkü 2007 yılı rakamlarıyla taksi soförlerinin aylık geliri ortalama 600-700 TL civarındadır. Bu gelir düzeyi ile ücretli taksi şoförleri, geçimlerini zorlukla sağlayabilmektedirler. Eskişehir'de, ticari taksiler için lisanslı hat fiyatlarının, taksi duraklarının bulunduğu mevkilere göre, 150,000 TL ile 250,000 TL arasında değiștiği göz önüne alındığında, ücretli taksi şoförlerinin, çalıştıkları iște kazandıkları ücretle lisanslı ticari taksiye sahip olabilmeleri imkânsız görünmektedir. İşini kaybeden bir taksi şoförünün bulabileceği en iyi iş yine ücretli şoför olarak benzer iş kollarında çalışmaya devam etmektir. İş bulma süreçlerinde şoförlerden oluşan sosyal çevrenin katkısı büyüktür. Bazı taksi şoförleri bu durumu şu şekilde ifade etmektedirler:

“Bu şimdiki çalıştı̆̆ım arabanın sahibi ar-
kadaşım çağırmıştı, bayramda işi varmış,
bayramda çalışıver diye. Gittik bayramda
onunla çalıştık. Ondan sonra işte diğer
şoför arkadaşlar dedi ki ya arkadaş sen de-
diler bu işten geçiniyorsun, başka bir iş bu-
lamadın, her gün bir şoförü dinlendir.
Haftada bir gün tatil yapıyorlar, ben çalış-

\begin{abstract}
tırlyorum arabayl."
"Şoförlïkten emekli olunca emekli maaşı yetmedi, baktım bir arayış içine girdim, dedim ben ne yapabilirim, şoför adamım, minibüslerde, taksilerde iş aramaya başladım, bu da bizim komşunun arabası yakın tanıdik, dedi benle çalışabilirsin dedi. 99'dan beri bu işte çalışıyoruz."

"Arabalarim sattıktan sonra iflas ettikten sonra arkadaşlarm sayesinde, onlarm taksilerinde taksiciliğe başladım. O zamandan bu yana da taksicilik yapıyorum"
\end{abstract}

Benzer bir durum apartman kapıcıları için de söz konusudur. Apartman kapicilarının çevreleri genellikle kendi meslek gruplarından olan kişilerden oluşmaktadır. Karşılıklı sosyal sermaye kullanımı yatay bir özellik arz etmektedir. Kapıcıların genellikle formel sektörde daha yüksek sosyal ve ekonomik statüye sahip mesleklerde çalışan bireylerle aynı apartmanda yaşıyor olmaları, dikey bir sosyal sermaye kullanımını sağlayamamaktadır. Çünkü apartman sakinleri üst katta, apartman kapiciları ise zemin katta oturmaktadirlar. Bu durum sosyal tabakalaşma piramidinin mekâna yansımış bir biçimi gibidir. Apartman sakinleri ile apartman kap1cılarının mekânsal ayrışması sosyal, kültürel ve ekonomik bir ayrışma ile iç içe geçmiştir. Bu ayrışma, dikey sosyal sermaye kullanımının hemen hiç olmadığı bir toplumsal ilişkiler ağını beraberinde getirmektedir. Böyle olduğu içindir ki, apartman sakinlerinin kapıcılarla olan ilişkisi daha çok hizmet alışverişi sürecinin ötesine pek geçmemektedir. Örneğin, apartman kapiciları ile apartman sakinlerinin komşuluk ilişkisi neredeyse hiç yoktur. Apartman sakinlerinin çocuklarının kapıcıların çocuklarıyla ilişkisi sınırlıdır. Kapıcilara asgari ücret üzerinden sigortalarının düzenli ödenmesi dişında formel sektörle benzeşen herhangi bir olanak sunulmamaktadır. Apartman kapıcılarının hepsi düzenli aylik gelire sahip olsalar bile asgari ücretle varabilecekleri en iyi yer, yoksulluk piramidinin kismen de olsa ortalarında tutunabilmektir. Aşağıda bazı kapıcıların kapıcılarla apartman sakinleri arasında kurulan, daha doğrusu kurulamayan sosyal ilişkilere yö- 
nelik ifadelerinden birkaçı bulunmaktadır. $\mathrm{Bu}$ ifadelerden de anlaşılacağı gibi kapıcılarin hizmetlerinde bulundukları kentsel orta sınıf üyeleri ile olan ilişkileri dikey bir sosyal sermaye kullanımını pek mümkün kılacak nitelikte görünmemektedir:

"İşte çocuğumu kapıcı çocuğu olarak görüyor, çоcuğumu "kapıcı çocuğu" diyorlar, hanımı da "kapıcı hanımı". Hatta çoğu yerde dediler sen bir kapicisin mesela affedersin, daha önce geldiğim yerde o yüzden bir kavga ettik. "Sen bir kapıcı köpeğisin" gibi kelimeler konuştu. Ve o yüzden de biraz zoruma gitti ve tartışma çıkardım."

"Öyle bir ayrum işte burda tek şeyi kapuclsin yani kapicı dairesi veya bir şey söylüyorsun mesela kapıcı dairesine şunu yaptırcaz dediğin zaman aman kapıcı dairesi değil mi az dursun gibicesine bir ayrimcilik var"

"Sen kapıcı çocuğusun, sen bir dışarı çık diyorlar, ondan sonra kendi aralarinda grup kurup oynuyorlar"

“Bir keresinde küu̧cük oğlum niçin anne biz aşağıda oturuyoruz da yukarıda oturmuyoruz sorusunu sordu. İlk zaten bu şekilde başlıyor. 'Neden biz aşă̆ıdayız, kapıdan girince neden aşă̆ıya iniyoz anne, biz de yukarı çıkalım, asansöre binelim' der. Bizim evimiz orda olsun, gibi. Bunlar çocuklara dokunuyor. Hele bir de mesela şu mahallede eğer onbeş yirmi yüz tane kaptcının çocuğu öğrenciyse, genelde iki yüz üçyüz tanesi de apartmanda oturanlarm çocukları. Ve bunlar arasında çok ayırımculık oluyor. Bizim çocuğa okulda sorarlarmış. Başka iş mi yoktuydu da bu işi yapryorsunuz? Isste sordukları zaman okulda, ben babam kapiculik yapıyor demekten utanıyorum. Çünkü birisi der makine mühendisi, birisi der Arçelik'teyim, birisi der şuyum biri buyum, ben kapıcı demekten utaniyorum der mesela."

Gündelikçi ve bakıcılar için de benzer bir durum söz konusudur. Tipkı apartman kapicıları gibi onlar da kentsel orta sinifla yakın bir temas halindedirler. Ancak orta s1nıfa yakınlığın gündelikçi ve bakıcılar açı- sindan da bu sinıfın sosyal sermayesinden yararlanmayla sonuçlandığ 1 pek söylenemez. Burada da sosyal, kültürel ve ekonomik açıdan bir mesafe söz konusudur. Orta sınıf için söz konusu olan, temizlik ve bak1c1lık hizmetlerinin yerine getirilmesidir. Bunun için ayrılan bütçe bellidir. Bu işleri yapan bakıcılardan ve gündelikçilerden istenen bu tür işlerin (bir takım ücretsiz ek işlerle birlikte) eksiksiz ve tam olarak yapılmasidır.

Bununla birlikte, ev-dişı hizmetlerde bulunan kapıcıların aksine, gündelikçi ve bakıc1ların kentsel orta sınıf ailelerinin ev-içi hizmetlerinde olmaları nedeniyle iki taraf arasındaki sosyal ilişkilerde paternalist nitelikte kimi yakınlaşmalar söz konusu olabilmektedir. Bu yakınlaşma gündelikçi ve bakıcılara genellikle küçük miktarlarda cep harçlığ ya da yiyecek ve kullanılmış giyecek yardımı gibi avantajların yanı sıra başka türden avantajlar da sağlayabilmektedir. Örneğin, bu yakınlaşma hastane, belediye, okul, dershane ve benzeri kurum ve kuruluşlara erişmede ya da bu kurumlara işleri düştügünde işlemlerini kolay yürütmede, az sayıda da olsa bazı gündelikçi ve bakıcılara işverenlerinin sosyal sermayelerini kısmi düzeyde de olsa kullanabilme imkânı sağlayabilmektedir. Bununla ilişkili olarak örneklemdeki kimi gündelikçi ve/ya bakıcılar evlerinde çalıștıkları orta sınıf ailelerin çevresini kullanarak hastanelerde siraya girmeden muayene olabildiklerini, kimisi okuyan çocuğuna burs bulabildiğini, kimisi belediyeden yakacak yardımı alabildiğini, kimisi de tanıdıklarına, düzensiz de olsa iș bulabildiğini beyan etmiştir. Kuşkusuz bu tür yardımlar gündelikçi ve bakıcıların kendi ailelerinin giderlerinin azaltılmasında önemlidir, ancak bu tip yardımların formel sektöre geçişi sağlayamayacağ 1 da son derece açıktır:

"Ne verirlerse onu alıyorum. Bazen denk gelir yiyecek de verirler, denk gelir giysi de verirler. Memnun oluyorum, seviniyorum. Kendim alamadiğım için ufacık şeyden mutlu oluyorum. Kendi gücüm yok, alamıyorum $k i . "$ 
"Önceki aile bakıcılık yaptığım, kızıma burs bağladı."

"Valilikten kömür, erzak almamıza sebep oldular."

"Üç kişiye buldum iş. Beni beğgendikleri için bana soruyorlar, bakıcıllk demek güven demek çünkü. Çocuklarımı bırakıyor insanlar, gözleri arkada kalmamalı"

"Ayakkabı aldılar daha iki gün önce. Să̆ olsunlar kışlık bir bot almışlar, benimkiler delinmişti. Düşüncelik yapmışlar. Verirler genelde işe yaramayanları. Ama bu botlar yeni."

"Üç sene bir doktorun evinde çalıştım. Onun bana çok faydası oldu Allah razı olsun. Eşim hastalanınca Tıp'ta bizimle çok ilgilendiler. Hiç kuyruk beklemedik çok iyi bakıldı onların sayesinde, hiç para almadılar, baktılar eşime."

"Yakıt ve yiyecek yardımı alıyorum, bu çocuğuna baktığım kadın ayarladı valilikten. Sağolsun arkadaşının eşi çalışıyormuş orada."

"Sabaha karşı rahatsızlandım, nefes alamamaya başladım, ondan sonra yanında çalıştığım aile hastaneye buraya gel, biz hemogramın falan her şeyini alırız dediler biz ilgileniriz, gösteririz cerraha dediler, Allah var, ilgilendiler, ilgilenmedi değil, hastanede doktor olunca ultrasonumu ameliyatım falan yaptırdilar. Para yeşil kart falan karşıladılar. Arkadaşıydı doktor, para istenmedi."

"Çocuğuna baktığım kişi diş doktoru. Dişlerimizi de yapıyor să̆ olsun. Hediye falan da alırlar"

Çok az sayıda gündelikçi ve bakıcı kadın ise işverenleri sayesinde, kendileri için olmasa bile, yakın akrabalarından bazıları için daha iyi çalışma koşullarına sahip işlere geçiş imkânı doğabilmektedir.

"Daha önceki patronumun gücü vardl, sözü her yerde geçerdi. Bana yakmlarmdan sadece birini işe sokabilirim dediydi. Hem kocam hem de kardeşim işsizdi. Kocamın hamaldır, hiçbir becerisi yok, eşya taşır. Kardeşim tornacı. Ben de hakkımı kardeşim için kullandım. Onu belediyeye soktu. Şimdi halen orda çalışıyor".

"Soba fabrikasında oğluma iş buldu yanında çalıştığım aile."

Kısacası, örneklem grubundaki dört meslek grubunun her birinin sosyal dayanışma ilişkiler ağı büyük ölçüde birbirine benzemekte ve yatay bir özellik arz etmektedir. Dikey ilişki ağlarına dayalı sosyal sermaye kullanımı ise her dört meslek grubunda neredeyse yok denecek kadar zayıftır. Dört meslek grubunda da sosyal sermayenin yatay kullanımı ise, en belirgin şekilde örneklemdekilerin kendilerine veya yakınlarına iş bulmaları sürecinde ortaya çıkmaktadır. Ancak bu sürecin de her zaman sorunsuz işlediği pek söylenemez. Nitekim çalışan yoksulların kentsel/enformel sektörde geliştirdikleri ilişkiler ağ 1 dayanışmanın yanı sıra güvensizliği ve rekabeti de içerebilmektedir. Örneğin, bu araştırmada örneklemde akraba, hemşeri ya da arkadaşlarına iş bulma konusunda yardım etmediğini belirtenlerden bazılarının ifadeleri kent yoksulları arasındaki güven ve karşılıklı yardımlaşma esasına dayalı dayanışma ağlarının her zaman güçlü olmadığını açıkça göstermektedir:

"Kimseye iş bulmadim. Önermiyorum, güven meselesi. İstemem yani kimseye kefil olamam. Çünkü evi ona teslim edecekler büyük sorumluluk"

"İsteyen oldu ama önder olmadım yani güvenemezsin, senden bilirler sonra."

"Öyle şeylere karışmadım güvenemezsin, arada sen kalırsin. Çocuk vardı bakılcak, bana da söylemişlerdi bul diye ama, bişey olur, sen kalırsin. Öyle şeylerden korkarim."

"Hiç bulmadık. İyilik yaparsın borçlu çıkarsın kızım, kötü olursun."

"Yok bulmadim, olsa da bulmam zaten, güvenmem kimseye. Bana ne herkes kendi bulsun."

"Benim zaten fazla işim yok, kime yardım 


\section{edeyim. Onlar yardım etti mi ki!"}

Yoksulların çevrelerindeki diğer bireylerin de kendilerine benzer durumda olmasina enformel işgücü piyasalarındaki rekabet de eklendiğinde, yoksulların kendi aralarında etkili sosyal ağlar kurmaları ve kullanmaları zorlaşmaktadır. Bu nedenle yoksullar orta s1nifa mensup tanıdıklarının sosyal sermayelerinden yararlanmaya çalışmaktadırlar. Ancak siniflı toplumlarda her zaman olduğu gibi farklı sınıflar kendi içlerindeki sosyal ağları kendi sınıfsal ayrıcalıklarını korumak ve sürdürmek için kullanmakta ve dişarıya büyük ölçüde kapatmaktadırlar. Örneğin, örneklemde borç para bulmak için bankadan kredi çekmek gibi formal yolları kullanabileceğini belirtenlerin oranı neredeyse $(\% 1,6)$ sıfırdır. Bir kapıcı bu durumu şu şekilde ifade etmiştir:

"işverenimden istedim, öyle bir ihtiyactm oldu, istedim işverenim vermedi. Bankaya gittim işte hani böyle 1 milyar falan civarunda şeye ihtiyactm oldu, bankada da o tür talepleri yani kapıcı gibi taleplere bizim kredimiz yok dediler geri çevirdiler. Kefil bulduğum halde geri çevirdiler".

Örneklem genelinde kredi kartı kullanım oranının aşağıda belirtildiği düzeyde düşük olması da benzer nedenlerden kaynaklanmaktadır. Formel finansal kaynakların büyük ölçüde enformel sektör çalışanlarına kapalı olması, çalışan yoksulların ekonomik ve sosyal güçlerini artırmalarını engellemektedir. İşverenleri aracıl1ğıyla orta sınıfın sosyal ağlarına eklemlenmede ve orta sinif mesleklere sahip olmada çalışan yoksulların eğitimsizliği önemli bir sorun haline gelebilmektedir. Örneklemdekilerden bazıları bu durumu şu şekilde ifade etmektedirler:

"Hiç kimseden çocuklarıma iş bulmalarım isteyemem ki. Senin çocukların okumamış diyorlar istediğimde.",

"Söyledim de üniversite mezunu arıorlar dedi, çocuğum işsiz, yardımcı olmuyorlar.",
"Başka okumuşluğum olmadiğı için. N'apacan ilkokul mezunu olunca fabrikaya almiyorlar.",

"...ilkokul mezunusun diye iş veren yok.", "Nereye gidersen git şimdi diploma soruluyor yani şimdi de öylee skiden de öyleydi yani.",

"Kapıcı olmak için sertifika olması lazım ...diplomanın gelmesi lazım. Onun için ben başuuramıyorum ama isterdim".

\section{Hane Düzeyinde Geçim Stratejileri}

Enformel sektörde düşük ücretle ve sosyal güvencesiz olarak çalışma, alt gelir gruplarının çeşitli geçim stratejileri geliştirmelerine neden olmuştur (Kalaycioğlu ve Rittersberger-T1lıç, 2000; Buğra ve Keyder, 2003). Yoksul ailelerin geçim stratejilerinde erkeğin yanı sıra kadının ve çocukların ücretli olarak çalışma yaşamına katılmasının önemli bir rolü vardır. Bunun yanı sıra eş-dost, hemşehri ve akraba yardımları, sivil toplum kuruluşlarından, derneklerden, vakıflardan ve kamu kurum ve kuruluşlarından yardım almak için girişimlerde bulunma, sağlık harcamalarını azaltmak için yeşil kart alma ve ek iş yapma gibi yol ve yöntemlerle yoksul hanelerin çeşitli geçim stratejileri geliştirdiği bilinmektedir (Kalaycıoğlu ve RittersbergerT1lıç, 2001; Altay, 2007). Kent yoksulları arasında, hane düzeyinde gelir artırıcı stratejiler kadar beslenme ve barınma maliyetlerini azaltmaya yönelik çeşitli stratejiler de geliştirilmektedir.

$\mathrm{Bu}$ araştırma kapsamında dört meslek grubundan örnekleme katılanların, gelir artırıcı ve gider azaltıcı yönde ne tür yol ve yöntemler kullandıklarını belirlemek amacıyla çeşitli sorular sorulmuştur. Bu çerçevede, örnekleme katılanların çalıştıkları işlerden elde ettikleri aylık gelirin dişında toplam hane gelirini tespit edebilmek için ek iş yapıp yapmadıkları, ek gelirlerinin olup olmadığ 1 ve eşlerinin gelir getiren bir işte çalışıp çalışmadığ 1 ile ilgili veriler de toplanmıştır. Buna göre örneklemdekilerin mesleklerinden elde ettikleri aylık gelir ortalaması 429 TL'dir. Verilere göre örnekleme katılanların \%10’u (40 
kişi) ek iş yapmaktadır. Ek iş yapan 40 kişinin çoğu (\%55'i) yaptıkları ek işten 2007 yılı itibarıla ayda 15-150 TL arasında değişen bir ek gelir elde etmektedir. Mesleklere göre ek iş yapma dağ 1 lımı incelendiğinde, en yoğun olarak ek iş yapan grup \%26 ile gündelikçiler arasında, en düşük yoğunlukta ek iş yapan grup ise \%11 ile kapicılar arasında gözlenmiştir. Yine verilere göre örneklemdekilerin \%13'ünün (53 kişi) işinden elde ettiği gelir dışında düzenli bir ek geliri bulunmaktadır. Ek geliri olan 53 kişinin çoğu (\%51) aylık 250 TL ve altında bir ek gelire sahip olduklarını belirtmişlerdir. Örneklemdekilerin \%54,3'ünün ise eşinin gelir getiren bir işte çalıștı̆̆ 1 saptanmıștır. Eşi çalışıyor durumda olanların eşlerinin işlerinden elde ettikleri aylık ortalama kazanç 477 TL'dir. Hane gelirini oluşturmadaki payları açısından eşlerin çalışma durumu değerlendirildiğinde, evli olan ve eşi sağ olan gündelikçilerin ve bakıcıların \%94'ünün eşi çalışırken, aynı durumdaki kapıcıların $\% 29^{\prime}$ unun, şoförlerin ise yalnızca \%9'unun eşinin çalıştığ1 gözlenmiştir.

Meslek gruplarının toplam geliri incelendiğinde (Tablo 3), kapıcıların aylık ortalama gelirinin 433 TL, eşi çalışanların eşlerinin gelirlerinin ise ortalama 322 TL olduğu gözlenmiştir. Şoförlerin aylık geliri ortalama 652 TL şoförlerden eşi çalışanların eşlerinin elde ettikleri ortalama aylık gelir 562 TL'dir. Gündelikçilerin ortalama aylık geliri 311 TL, eşlerinin geliri ise ortalama 470 TL'dir. Bakıcıların ortalama aylık geliri $321 \mathrm{TL}$ ve eşlerinin ortalama geliri 526 TL'dir. Şoförler, aylık gelir ve eşin kazancı acısından diğer gruplardan göreceli olarak daha yüksek ka- zanç elde etmektedir.

Her dört meslek grubundaki çalışan yoksulların önemli bir bölümü gelir-gider dengesini sağlamada çok büyük güçlükler çekmektedir. Nitekim örneklem grubunun üçte ikisi borçlu olduğunu ifade etmiştir. Mesleklere göre örnekleme katılanların borç miktarları incelendiğinde en yüksek miktarda borcu olan grubun gündelikçiler $(4,299$ TL) olduğu görülmüsstür. Örneklemdekilerin \%47'si ihtiyaçları olduğu anda borç bulabileceklerini, borç bulabileceğini belirtenlerin büyük çoğunluğu da (\%81) borcu akraba ve arkadaş gibi yakın çevrelerinden bulabileceklerini belirtmişlerdir.

Bununla birlikte, örneklemin \%54'ü belirli miktarda bir paraya ihtiyaç duymaları halinde borç isteyebilecekleri kimsenin olmadığını belirtmektedirler. Borç bulabilecek kimsesi olmayanların temel çaresizliği, bir taraftan yardımlaşacak kimselerinin ve bağlantılarının olmaması, diğer taraftan, yardım edecek kimseleri olanların etraflarındaki insanların da ancak zar zor geçinebilecek düzeyde olmalaridir. $\mathrm{Bu}$ durum da örneklemdeki çalışan yoksulların içinde bulundukları sosyal ilişkiler ağının yatay niteliğine işaret etmektedir. Örneklemdeki çalışan yoksullardan bazıları bu durumu şu şekilde ifade etmektedirler:

"Hiç kimse yok, vallahi yok. En fazla alacağımı, apartmanlardan önceden paramı alırım. Onun dişında benden başka kimsem yok.",

"Kimseden alamam, herkesin kazancı kendine yetmiyor hiç almadık, alamayız da.",

Tablo 3

Aylık Gelir Durumu

Nakit Gelir Ortalamaları (TL)

\begin{tabular}{|c|c|c|c|c|c|}
\hline$\%$ & $\begin{array}{c}\text { Kap1c1 } \\
\mathrm{n}=\mathbf{1 0 0}\end{array}$ & $\begin{array}{l}\text { Şoför } \\
\mathrm{n}=100\end{array}$ & $\begin{array}{c}\text { Gündelikçi } \\
n=100\end{array}$ & $\begin{array}{l}\text { Bak1c1 } \\
n=100\end{array}$ & $\begin{array}{c}\text { Toplam } \\
n=400\end{array}$ \\
\hline Aylık Gelir & 433 & 652 & 311 & 321 & 429 \\
\hline Eşin Geliri & 322 & 562 & 470 & 526 & 464 \\
\hline Toplam Gelir & 755 & 1,214 & 781 & 847 & 893 \\
\hline
\end{tabular}


"Kimden alacă̆ım, herkes benden fakir. Herkesin kendi ihtiyactna parası yetmiyor.",

"Borç bulabileceğgim kimse yok. En fazla 10

TL bulabilirim. Komik di mi, ama gerçek bu."

Örneklemde yer alanların yalnızca \%21'inin kredi kartı bulunmaktadır. Kredi kartına sahip olanların yarisından fazlasinin ise (\%63) kredi kartı borcu bulunduğu gözlenmiştir. En yoğun kredi kartı kullanımı (\%29) şoförler arasında görülmektedir. Kredi kartını en az kullananlar ise \%18 ile kapicilar ve gündelikçilerdir. Buna karşın kredi kartına en fazla borcu olanlar da \%83 ile gündelikçilerdir.

Örneklem grubu içinde, borçlu olup borcunu ödemede güçlük çekenlerin ortalama borç miktarının ise ortalama 3,635 TL olduğu gözlenmiştir. Bu çok ciddi bir borçlanma oranidir. Zira bu oran örneklemdekilerin yukarıda hesaplanan aylık gelirlerinin oldukça üstünde görünmektedir ve mevcut ücret düzeyi ile nasıl kapatılabileceği belirsizdir.

Borçların büyük çoğunluğunu düğün masrafları, kredi kartı borçları, ev eşyası taksitleri gibi kalemler oluşturmaktadır:

"Taksitlerimiz var, şu an televizyonun 50

TL taksiti var";

“Düğünlerde oldu. Oğlanın eşyalarmı aldık işte, borçlandik.";

"Taksitler var işte, çekyat taksitleri. Çok değil ama olmayınca çok geliyor, 28 milyon taksit, ödeyemiyoruz şu anda.";

"300 TL elektrik borcu var. Sigortadan kaçak kullanıyoruz şu anda. 400 telefona, 800-1000 TL de su birikmiş";

"Kizımin dershane masrafları var, 600 milyonla geçimimi sağlayamıyorum, kızımin yol parası 30 milyon tutuyor, onlar benim için hep külfet, önceden ayrı koymam lazım";

"Düğün yaptım bir buçuk ay önce. Yanında çalıştığım doktor hanımlardan borç aldım, ödüyorum onu".
Borcu olmayanların, ödeyememe endişesiyle borçlanmaktan çekindikleri gözlenmiştir. Örneklemdeki çalışanlardan bazıları bu durumu şu şekilde ifade etmişlerdir:

"Hiçbir yere yapmıyorum. Varsa giderim yoksa gitmem, yapmam borç. Yetişkin kızım var, çeyiz falan hiçbir şey yapmıyorum, üstüme giyecek bir şey almıyorum";

"Güvenip de kendimize girmiyoz zaten";

"Yok ki, ne alayım da ne borcum olsun";

"Yok. Ayağımızı yorganımıza göre uzatıyoz işte";

"Büyük bişeye giremeyiz ki. Aldığın asgari ücret nasil büyük bir borca girecen ki"

"Zaten kredi kartı borcu nedeniyle iflas ettik, zaten bu yüzden işe girdim".

Örneklem grubunun hane gelirini arttırıc1 geçim stratejileri incelendiğinde \%11'inin belediye, valilik ya da yeşil kart yoluyla sosyal yardım aldıkları, yardım alanların büyük çoğunluğunun (\%77) tek yerden yardım almasina karşılık, \%19'unun iki yerden yardım aldığı, \%4'ünün ise bu yardımların tümünü aldıkları görülmüştür. Meslek gruplarına göre en çok sosyal yardım alanların (\%19) gündelikçiler, en az sosyal yardım alanların ise (\%1) kapıcılar olduğu gözlenmiştir. Benzer biçimde iki ya da daha fazla yerden sosyal yardım alanlar içinde en büyük grubu gündelikçilerin oluşturduğu görülmektedir. Yine, memleketten en fazla yardım alanların \%26 ile gündelikçiler olduğu, bu yardımların büyük çoğunluğunun (\%89) erzak yardımı biçiminde olduğu gözlenmiştir (bkz. Tablo 4).

Örneklem grubunda yer alanlara bir ailenin rahat yaşayabilmesi için gerekli olan aylık gelirin ne olması gerektiği şeklinde bir soru da yöneltilmiştir. Örneklemde yer alanların yarısından fazlası (\%56) 1,000 TL'den az bir aylık gelirin gerekli olduğunu, örneklemin \%38'i de 1,000 ile 2,000 TL arasında değişen bir aylık gelirle bir ailenin rahat yaşayabileceğini belirtmişlerdir. Örneklem grubunda yer alanların yarısından fazlasının bir ailenin rahat yaşayabilmesi için gerekli olan aylık geliri için 1,000 TL'den daha az bir 
Tablo 4

Örneklemin Sosyal Yardım Alanların Oranına Göre Dağılımı

\begin{tabular}{|c|c|c|c|c|c|}
\hline$\%$ & $\begin{array}{c}\text { Kap1c1 } \\
\mathrm{n}=100\end{array}$ & $\begin{array}{l}\text { Şoför } \\
\mathrm{n}=100\end{array}$ & $\begin{array}{c}\text { Gündelikçi } \\
n=100\end{array}$ & $\begin{array}{l}\text { Bak1c1 } \\
n=100\end{array}$ & $\begin{array}{c}\text { Toplam } \\
n=400\end{array}$ \\
\hline $\begin{array}{l}\text { Sosyal yardım alıyor mu? } \\
\text { Evet } \\
\text { Hayır }\end{array}$ & $\begin{array}{c}1 \\
99\end{array}$ & $\begin{array}{l}13 \\
87\end{array}$ & $\begin{array}{l}19 \\
81\end{array}$ & $\begin{array}{l}10 \\
90\end{array}$ & $\begin{array}{l}11 \\
89\end{array}$ \\
\hline $\begin{array}{l}\text { Kaç yerden yardım alıyor? } \\
\text { Bir } \\
\dot{I ̇ k i} \\
\ddot{U}_{c ̧}\end{array}$ & $\begin{array}{c}100 \\
- \\
-\end{array}$ & $\begin{array}{c}92 \\
8 \\
-\end{array}$ & $\begin{array}{l}58 \\
32 \\
10\end{array}$ & $\begin{array}{l}90 \\
10 \\
-\end{array}$ & $\begin{array}{c}77 \\
19 \\
4\end{array}$ \\
\hline $\begin{array}{l}\text { Memleketten yardım geliyor mu? } \\
\text { Evet } \\
\text { Hayır }\end{array}$ & $\begin{array}{l}17 \\
83\end{array}$ & $\begin{array}{c}7 \\
93\end{array}$ & $\begin{array}{l}26 \\
74\end{array}$ & $\begin{array}{l}19 \\
81\end{array}$ & $\begin{array}{l}17 \\
83\end{array}$ \\
\hline $\begin{array}{l}\text { Memleketten ne tür yardım geliyor? } \\
\text { Erzak } \\
\text { Nakit } \\
\text { İkisi de }\end{array}$ & $\begin{array}{c}94 \\
6 \\
-\end{array}$ & $\begin{array}{l}100 \\
- \\
-\end{array}$ & $\begin{array}{c}89 \\
8 \\
3\end{array}$ & $\begin{array}{l}68 \\
16 \\
16\end{array}$ & $\begin{array}{c}85 \\
9 \\
6\end{array}$ \\
\hline
\end{tabular}

rakam telaffuz etmesi birçok açıdan gelecekte yoksulluktan kurtulma konusunda duyulan umutsuzluk ile yakından ilişkilidir:

"600-700 TL olsa gayet rahat geçinirim. Sen zenginlere bakma onlar 3-4 milyar da alsa yetinemiyor. Ben tutmaya, tutturmaya alıskınım. 50 TL'ye alacağıma 15'e ayakkabı alırım bu kadar basit. Sağllk olsun yeter."

"Çok da değil. 600-700 olsun fazlasinda şeyim yok. Yeter ki olsun. O bana şey. Çok para da azdırur derler ya.";

"Şimdi biz bu durumda 700'e bile çok rahat yaşarız da, bizim için çok büyük bir para. 1,5 civarı olsa biz de lüks yaşarı. O da kendi çapımızda, ortam olarak değil de yani. Bir restorana yemek yemeye gitmiyoruz yani".

"600 yeter de artar. Olsun, kimseye bakmam. 100 yemek, 100 faturalar, geri kalanı yeter de artar.";

"700-800 olsa geçiniriz rahat işte. Bir milyar alsa daha da rahat yaşarız, nerdeee?"

Bununla birlikte, örneklemin önemli bir bölümü için aylık 1,000 TL'nin üzerindeki bir gelir düzeyi, rahat bir yaşam standardına sahip olabilmek için önemli bir eşiktir:
"Bir milyar olmalı herhalde. Şu eksik, yetişmedi demezsin o zaman. İhtiyactnı öbür aya ertelemezsin";

"Bir milyar de, o kadar parayı görmedim ki, hiç bilmiyorum.";

"Benim var ya, ihtiyaç için değil de, şu evi bir deŏiştirebilmek için isterim yani, şöyle bir 500 milyonluk bi dairede oturmayı. 500 kira, 200 yakıt, 100 faturalar desen bak 800. aylik 1,5 milyar para lazım ki yaşayasın. Çocuklarm hafta hafta dergileri geliyor bak, aylik 30 milyon nerdeyse iki çocuğa elli milyon surf ona gidiyo, kurtasiyeyle birlikte 100 gider bak aylik. Ki benim çocuklarım çok tutumludur."

"En azından bir milyar bir buçuk milyar olsa rahatça yesen olmaz mi? Şimdi giderler ilerledi, elektrik su telefon, giderim gelirim kadar olmalı ki rahat edesin.";

"Bir milyar anca denk gelir, insanlar doyumsuzdur, evin olduktan sonra 600-700 de yeter.";

"En aşağı bir milyar olmalı, benim bir milyarım olsa istediğim gibi yaşardım."

Gelir gider dengesini sağlamada barınma, yiyecek, giyecek, ev eşyası ile tatil ve sinema 
gibi sosyal ihtiyaçlar ile ilgili masrafları azaltmaya yönelik geçim stratejiler de çok önemli bir rol oynamaktadır. Barınma masrafları açısindan bakıldığında örneklemde yer alanların yalnızca \%29'u mülkiyeti kendilerine ait bir evde yaşamaktadır. Bununla birlikte, örneklemin \%34'ü kapıcı dairesinde, \%9'u da akrabalarina ait evlerde kira vermeden yaşamaktadırlar. Yaşadıkları konut karşı1ığında kira ödemek durumunda olanların oranı ise \%26'dır. Çalışan yoksulların önemli bir bölümünün (\%43) ev sahibi olmadığı halde kapıcı dairesi veya akrabalara ait evlerde kira vermeden yaşamaları onları kente tutunabilmek için oldukça önemli bir masraftan korumaktadır.

Örneklemde yer alanların yaşadıkları evler en sıklıkla 2 odalı (\%60) ve 3 odalı (\%32) evlerdir. Örneklem grubunun \%7'si ise tek odalı evlerde yaşamaktadır. Cevaplayıcıların \%42'sinin evinde salon, \%51'inin ise evinde çocuklara ait bir yatak odası bulunmamaktadır.

Tablo 5

Örneklemde Yer Alanların Barınma, Ev Eşyası ve Çeşitli Sosyal İhtiyaçlar Açısından Durumu

\begin{tabular}{|c|c|c|c|c|c|}
\hline$\%$ & $\begin{array}{c}\text { Kap1c1 } \\
\text { n=100 }\end{array}$ & $\begin{array}{l}\text { Şoför } \\
\text { n=100 }\end{array}$ & $\begin{array}{c}\text { Gündelikçi } \\
n=100\end{array}$ & $\begin{array}{c}\text { Bak1c1 } \\
n=100\end{array}$ & $\begin{array}{c}\text { Toplam } \\
n=400\end{array}$ \\
\hline $\begin{array}{l}\text { Evin mülkiyeti } \\
\text { Kendisinin } \\
\text { Akrabanın } \\
\text { Kira } \\
\text { Kapı dairesi } \\
\text { Diğer }\end{array}$ & $\begin{array}{c}- \\
- \\
- \\
93 \\
7\end{array}$ & $\begin{array}{c}50 \\
14 \\
36 \\
- \\
-\end{array}$ & $\begin{array}{c}24 \\
11 \\
31 \\
34 \\
-\end{array}$ & $\begin{array}{c}42 \\
12 \\
38 \\
8 \\
-\end{array}$ & $\begin{array}{c}29 \\
9 \\
26 \\
34 \\
2\end{array}$ \\
\hline $\begin{array}{l}\text { Evinde salon var mı? } \\
\text { Evet } \\
\text { Hayır }\end{array}$ & $\begin{array}{l}24 \\
76\end{array}$ & $\begin{array}{c}95 \\
5\end{array}$ & $\begin{array}{l}49 \\
51\end{array}$ & $\begin{array}{l}65 \\
35\end{array}$ & $\begin{array}{l}58 \\
42\end{array}$ \\
\hline $\begin{array}{l}\text { Evinde çocuk odası var mı? } \\
\text { Var } \\
\text { Yok }\end{array}$ & $\begin{array}{l}32 \\
68\end{array}$ & $\begin{array}{l}57 \\
43\end{array}$ & $\begin{array}{l}46 \\
54\end{array}$ & $\begin{array}{l}61 \\
39\end{array}$ & $\begin{array}{l}49 \\
51\end{array}$ \\
\hline $\begin{array}{l}\text { Evde eksikliğini hissettiği eşya? } \\
\text { Var } \\
\text { Yok }\end{array}$ & $\begin{array}{l}64 \\
36\end{array}$ & $\begin{array}{l}51 \\
49\end{array}$ & $\begin{array}{l}65 \\
35\end{array}$ & $\begin{array}{l}59 \\
41\end{array}$ & $\begin{array}{l}60 \\
40\end{array}$ \\
\hline $\begin{array}{l}\text { Tatilde ne yapar? } \\
\text { Evde kalır } \\
\text { Köye/akrabalarına gider } \\
\text { Tatile gider } \\
\text { Çalışmaya devam eder } \\
\text { Diğer }\end{array}$ & $\begin{array}{c}12 \\
53 \\
2 \\
30 \\
3\end{array}$ & $\begin{array}{c}20 \\
12 \\
10 \\
52 \\
6\end{array}$ & $\begin{array}{c}35 \\
44 \\
7 \\
13 \\
1\end{array}$ & $\begin{array}{c}43 \\
38 \\
5 \\
10 \\
4\end{array}$ & $\begin{array}{c}28 \\
37 \\
6 \\
26 \\
3\end{array}$ \\
\hline $\begin{array}{l}\text { Sinema } \\
\text { Gitmez } \\
\text { Gider }\end{array}$ & $\begin{array}{c}95 \\
5\end{array}$ & $\begin{array}{l}84 \\
16\end{array}$ & $\begin{array}{c}91 \\
9\end{array}$ & $\begin{array}{l}77 \\
23\end{array}$ & $\begin{array}{l}87 \\
13\end{array}$ \\
\hline $\begin{array}{l}\text { Tiyatro } \\
\text { Gitmez } \\
\text { Gider }\end{array}$ & $\begin{array}{c}95 \\
5\end{array}$ & $\begin{array}{c}96 \\
4\end{array}$ & $\begin{array}{c}95 \\
5\end{array}$ & $\begin{array}{l}85 \\
15\end{array}$ & $\begin{array}{c}93 \\
7\end{array}$ \\
\hline $\begin{array}{l}\text { Konser } \\
\text { Gitmez } \\
\text { Gider }\end{array}$ & $\begin{array}{c}91 \\
9\end{array}$ & $\begin{array}{l}88 \\
12\end{array}$ & $\begin{array}{l}79 \\
21\end{array}$ & $\begin{array}{l}72 \\
28\end{array}$ & $\begin{array}{l}83 \\
17\end{array}$ \\
\hline $\begin{array}{l}\text { Lokanta } \\
\text { Gitmez } \\
\text { Gider }\end{array}$ & $\begin{array}{l}81 \\
19\end{array}$ & $\begin{array}{l}15 \\
85\end{array}$ & $\begin{array}{l}62 \\
38\end{array}$ & $\begin{array}{l}47 \\
53\end{array}$ & $\begin{array}{l}51 \\
49\end{array}$ \\
\hline
\end{tabular}


Yiyecek, giyecek, ev eşyası ve benzeri ihtiyaçlar açısından bakıldığında ise örneklemde yer alanlar en çok bir evde bulunması gereken çeşitli eşyaların, bir başka deyişle dayanıklı tüketim mallarının eksikliğinden söz etmişlerdir. Bu açıdan örneklemde yer alanların \%60'ı evlerinde çeşitli eşyaların eksikliğini hissettiklerini söylemişlerdir (bkz. Tablo 5).

Sosyal ihtiyaçlara yönelik masrafların kısılması anlaminda örnekleme girenlerin tatile, sinemaya, tiyatroya, konsere ve lokantaya ne sıklıkla gittikleri incelendiğinde, çok küçük bir azınlığın (\%6) genellikle deniz kenarına tatile gittiği, \%28'inin tatilde evde oturduğu, $\% 26$ 'sının ise tatilde çalışmaya devam ettiği gözlenmiştir. Benzer biçimde \%87'si sinemaya, \%93'ü tiyatroya, \%83'ü konsere, $\% \% 51$ 'i lokantaya hiç gitmediklerini belirtmişlerdir (bkz. Tablo 5).

Tablo 5'deki durumu kısaca özetleyecek olursak dört meslek grubundan örnekleme kat1lanlar ücretli işlerde çalışıyor olmalarına karşın kentsel orta sınif standartlarınin oldukça altında bir yaşam sürdürmektedirler. Bu bakımdan örneklem grubu kapsamındaki dört meslek grubunun tüketim toplumuna eklemlenebildikleri pek söylenemez. Aşağıda verilen ifadelerden de anlaşılacağ 1 gibi, düşük ücretli olarak istihdam edilen bakıcılar, gündelikçiler, şoförler ve kapıcılar geçinebilmek için ister istemez belli harcamalardan kaçınmak zorunda kalmaktadırlar.

"Eve patates sokmak istemiyor insan. Sabah akşam patates."

"On milyonluk peynir yerine üç milyonluk yiyorum, giyimden kısiyorum."

"Ilk başta eşyadan keserim. Yani o olmazsa olmayabilir. Ama çocuğum giyinecektir, büyüyordur mesela o giyinecektir, ya da yiyeceğiz, hani boğaz her daim bir şeyleri yemeyi içmeyi istiyor yani. Fuzuli masraf olarak satin almamazlik edemem"

"Et almam, en çok boğazdan kısıtlarım, 15 günde bir çalıştırırım elektrik süpürgesini, doğalgazı kısarım. Giyimi almam yardımlarn giyerim. Eskileri giyerim. Pazarlik yaparım. Ekmek yaparım."

"Her şeyi kendim yaparım, salça, turşu.
Giysi almam fazla. Elektriğe dikkat ederim, lambalara. Ütülenecek her şeyi ütülemem sadece bazı giyecekleri".

"Kuru baklagilleri kış girmeden böyle şeyle toptancilardan alıyorum, büyük şeylerle, beş kilo on kilo alıp koyuyorum, o da yaza kadar kullanıyoruz."

"Maaştan maaşa mesela tavuğunu alırsan eti olmaz, etini aldın tavuğu olmaz, birisi vardır, birisi yoktur mesela."

"Lokantaya vereceğime giderim bir kilo tavuk, et alırm evde çocuklarmmla yerim."

"Kemerimiz kalmadı sikılacak. Kurbandan kurbana et görüyoz."

"Her gün tavuk yesen, et yesen, pahal şeylerden yesen dăg gibi de paran olsa yetişmez. Her şeyi yeteceŏi kadar alacaksın."

Örnekleme girenlerin hanelerinin mekânsal özelliklerine ve tüketim alışkanlıklarına genel olarak bakıldığında, çalışan yoksulların hane giderlerini azaltmada tüketimi kısma/azaltma stratejilerinin çok önemli bir rol oynadığ1 görülmektedir. Yoksulluk, birçok mahrumiyeti beraberinde getirmektedir ve temel gereksinimleri karşılayamama durumu bunların başında gelmektedir. Bauman'a göre (1999) kapitalizmin önceki dönemlerinde yoksulluk olgusu işsizlikle önemli ölçüde bağlantılıydı. Oysa günümüzde yoksullar yalnızca işsizler değildir. Artık, istihdam edildiği halde tüketemeyen çok geniş bir toplumsal kesimin varlığından söz edebilmek mümkündür. Bauman'ın da belirttiği gibi, tüketememe durumu yoksulluğun en önemli ölçütlerinden biri haline gelmektedir (1999). Araştırmanın kapsamındaki örneklem grubunun çok büyük bir çoğunluğunun sinemaya, tiyatroya, konsere, tatile ve benzeri yerlere gidememesi Bauman'ın açılamalarıyla örtüşmektedir.

Örneklem grubundaki çalışan yoksulların Buğra ve Keyder'in (2003) öne sürdüğü şekliyle sosyal ilişkiler ağıyla iyileştirilemeyecek ölçüde bir yoksulluk sarmalı içerisinde olduğu söylenebilir. Ancak örneklem grubuna giren dört meslek grubu yoksullukla baş etme stratejileri açısından kendilerini kısmen de olsa başarılı görebilmektedirler. Az gelirle idare edebilme ve zorunlu harcamalarda en azı ile yetinebilme ile ilgili belirli geçim stra- 
tejileri geliştirdikleri görülmektedir. Bununla birlikte "kendi yağıyla kavrulma" stratejisi örneklemdeki meslek gruplarının bir bölümü için pek geçerli değildir. Zira kimi çalışan yoksullar tüketim ile ilgili harcamalarda belli bir kısıntıya gitmiş olsalar bile yüklü bir borç altına girmekten kaçınamamışlardır. Büyük bir borç yükü altına girmiş olanlar Buğra ve Keyder'in (2003) belirttiği gibi sosyal ilişkiler ağ1 ile iyileştirilemeyecek düzeyde bir yoksulluk çıkmazı içerisindedirler. Zira örneklem grubundaki çalıșan yoksulların yarısından fazlası acil bir paraya ihtiyacı olsa bile çevresindeki hiçbir kimseden borç bulamayacağını ve yine her beş kişiden birisi ödemesi neredeyse mümkün olamayacak bir borç yükü altında olduğunu belirtmiştir.

Örneklem grubundaki dört meslek grubunun yaşam stratejilerinin önemli ölçüde tüketimi azaltmaya yönelik olması, düşük ücretli ve sosyal güvencesiz olarak çalışmalarıyla yakından ilișkilidir. Örneklem grubundaki bireylerin düşük ücretli ve sosyal güvencesiz olarak çalışmaları, en temel gereksinimlerini bile tüketmemeleri sonucunu doğurmaktadır. Bu da ister istemez insani yoksulluk ölçütleri açsından örneklem grubundaki bireylerin derin bir yoksulluk deneyiminden çok da uzak olmadıkları anlamına gelmektedir.

\section{SONUÇ}

Çalışan yoksullar olgusu, başta işgücü piyasası olmak üzere belirli ekonomik ve toplumsal ilişkiler sonucu ortaya çıkan çok yönlü bir olgudur. Ancak çalışan yoksulların yoksullukla baş etme stratejilerini de benzer dinamikler üzerinden geliştirdiği söylenebilir. Gelir artırıcı ve gider azaltıcı stratejiler ile sosyal sermaye kullanımı bu dinamiklerin en önemlileri olarak karşımıza çıkmaktadır. Bununla birlikte son zamanlarda yoksullukla baş etme stratejilerinde piyasa dinamikleri yerine sosyal sermayeyi artıracak güçlü ve zengin sosyal ilişkiler ağı geliştirme üzerinde daha çok durulduğu görülmektedir.

$\mathrm{Bu}$ çalışmada da ortaya konulduğu üzere yoksulların var olma stratejilerinde sosyal ilişkiler ağı son derece önemli bir yere sahiptir. Ancak geleneksel dayanışma ağlarının kentlerde giderek önemini yitirmeye başla- ması, kentsel işgücü piyasasında bireyleri yeni sosyal ilişkiler oluşturmaya yönlendirmektedir. Örneklem grubuna dahil olan dört meslek grubunun sahip olduğu sosyal sermayenin kullanımı yatay bir özellik arz etmektedir. Sosyal sermayenin yatay kullanımı bireyleri enformel sektörün belirsizliğinden ve güvencesizliğinden kurtaramamaktadır. Örneklemdeki dört meslek grubunun kentsel orta sınıf tarafından istihdam edilmesi sosyal sermaye kullanımında dikey bir ilişkiyi ortaya çıkaramamaktadır. Bunun birçok nedeni bulunmaktadır. Bu nedenlerin başında çal1şan yoksulları istihdam eden kentsel orta s1nifın sahip olduğu sosyal sermayenin de sinurlı ve yetersiz olması gelmektedir. Sosyal sermayenin sinırlı ve yetersiz olması, kentsel orta sınıfı, içe dönük bir ilişkiler ağını kullanmaya ve istihdam ettiği çalışan yoksulları dışlamaya zorlamaktadır. Diğger taraftan orta sinif sosyal sermaye olanaklarından yararlanma beklentisi içerisinde olan hizmet sektörü çalışanları, gündelik yaşam deneyimleri sonucunda, bu konuda belirli bir hayal kırıklığına çoktan uğramış durumdadırlar. Orta sinıf tarafından dışlanmışlık durumu, çalışan yoksulların içe dönük geçim stratejileri geliştirmelerine neden olmaktadır. Bu da çalışan yoksullar açısından geliri artırma, giderleri ise mümkün olabildiğince azaltma üzerine kurulu bir daimi yoksulluk döngüsüne neden olmaktadır. Çünkü çalışan yoksulların geçim stratejileri, yukarıya doğru hareketlilik şansinı arttırmaktan çok derin yoksulluğa ve açlık sınırının altına düşmeme bağlamında önemli bir rol oynamaktadır.

Formel sektöre ulaşmayı mümkün kılabilecek ilişkiler ağının dişında olmak demek, enformel sektördeki yoksulluk açmazının içinde kalmak demektir. Bu durum enformel sektördeki bireyleri, gözlerden irak bir insanî yoksulluk sarmalıyla karşı karşıya bırakmaktadır. Bu yoksulluk deneyimi öylesine ironiktir ki, bireyler kendilerini ne kadar çok yoksullaştırırlarsa o kadar çok var olabileceklerdir. Daha açık ifade etmek gerekirse, çalişan yoksullar için var olmanın temel dayanağ1, düşük ücretli de olsa her zamankinden daha fazla çalışmak ve her geçen gün mümkün olduğunca daha az tüketmektir. 


\section{KAYNAKÇA}

Adaman F. ve Keyder, Ç. (2005). Türkiye'de Büyük Kentlerin Gecekondu ve Çöküntü Mahallelerinde Yaşanan Yoksulluk ve Sosyal Dışlanma. Avrupa Komisyonu için hazırlanan rapor. http://ec.europa.eu/employment_social/social_inclusion/docs/2006/study_turkey_tr.p df. (21.12.2008).

Aktan, C. C. (2002). Yoksullukla Mücadele Stratejileri. Hak-İş Konfederasyonu Yayınları. http://www.canaktan.org/ ekonomi/ yoksulluk/dorduncu-bol/ aktan-vuralyoksulluk-oneriler.pdf (06.03.2009).

Altay, A. (2007). “Bir Kamu Malı Olarak Sosyal Sermaye ve Yoksulluk İlişkisi". Ege Akademik Bakış. Cilt:7, Sayı:1, ss. 337-362.

Ayata, A. (1989) “Gecekondularda Kimlik Sorunu, Dayanışma Örüntüleri ve Hemşehrilik", Sosyal Bilimler Kongresine Sunulan Tebliğ, ODTÜ Ankara.

Bane, M. J. ve Ellwood, D. (1991) “Is American Business Working for Poor?" Harvard Business Review. Eylül Sayısı, ss. 58-66.

Bauman, Z. (1999). Çalışma Tüketicilik ve Yeni Yoksullar. Sarmal Yayınevi. İstanbul.

Bora A. (2005). Kadınlar Sınıfı: Ücretli Ev Emeği ve Kadın Öznelliğinin İnşası. İletişim Yayınları, İstanbul.

Bourdieu, P. (1986). “The Forms of Capital". İçinde: Richardson, J. (Ed.). Handbook of Theory and Research for the Sociology of Education. Westport CT: Greenwood Press, New York.

Bradshaw, J., Finch, N., Kemp, P.A., Mayhew, E. ve Williams, J. (2003). Gender and Poverty in Britain. Equal Opportunities Commision, Working Paper Series, No: 6, Manchester. http://www.eoc.org.uk /PDF/genderandpoverty.pdf (20.02.2009).

Braverman, H. (1974). Labour and Monopoly Capital. Monthly Review Press, New York.

Buğra, A. ve Keyder, Ç. (2003). New Poverty and the Changing Welfare Regime of Turkey. UNDP, Ankara. http://www.undp.org.tr/ publicationsDocuments/new_poverty.pdf (02.04.2009).
Buğra, A. ve Keyder, Ç. (2006). Sosyal Politika Yazlları. İletişim, İstanbul.

Chen, W.H. (2005). "Examining the Working Poor in Canada: Is Working a Ticket Out Of Poverty?". Family and Labor Studies Statistics Canada. http://economics.ca/2005/papers/0240.pdf (15.04.2009).

Chen, M., Vanek, J., Lund, F., Heintz, J., Jhabvala, R. ve Bonner, C. (2005). "Progress of the World's Women 2005: Women, Work and Poverty". UNIFEM (United Nations Development Fund For Women).

http:/ / www.unifem.org/attachments / products/PoWW2005_eng.pdf (10.06.2009).

Coleman, J. C. (1988). "Social Capital in the Creation of Human Capital". American Journal of Sociology. Sayı:94, ss. 95-120.

Cooper, C. L. ve Lewis, S. (1999). "Gender and the Changing Nature of Work". İçinde: Powell, G. N. (Ed.) Handbook of Gender and Work. Sage, London.

Danziger, S. ve P. Gottschalk. (1986), “Work, Poverty, and the Working Poor: A Multifaceted Problem". Monthly Labor Review. Eylül Say1s1, ss. 17-21.

DPT (2001). Nitelikli İnsan Gücü, Meslek Standartları Düzeni ve Sosyal Sermaye Birikimi. Sekizinci Beș Yıllık Kalkınma Planı, Özel İhtisas Komisyonu Raporu. DPT, Ankara.

Ecevit, Y. (2000). “Çalışma Yaşamında Kadın Emeğinin Kullanımı ve Kadın Erkek Eşitliği". Kadın-Erkek Eşitliğine Doğru Yürüyüş: Eğitim, Çalışma Yaşamı ve Siyaset. TÜSİADT/2000-12/290, İstanbul.

Ehrenreich, B. (2002). Nickel and Dimed: On (Not) Getting By in America. Henry Holt \& Company, New York.

Erder, S. (1996), İstanbul'a Bir Kent Kondu: Ümraniye, İstanbul: İletişim.

Erdut, T. (2005). “İşgücü Piyasasında Enformelleşme ve Kadın İşücü". Çalışma ve Toplum. Cilt:6, Sayı:3, ss. 11-49.

Erdut, E. (2007). Enformel İstihdamin Ekonomik ve Sosyal Etkileri. Çalışma ve Toplum. 2007/1, 
http:/ /www.calismatoplum.org/sayi12 /Erdut.pdf , (25. 06. 2009).

Erdoğan, G. (2002) “Türkiye'de ve Dünyada Yoksulluk Ölçümleri Üzerine Değerlendirmeler" içinde: Aktan, Can C. (ed.) Yoksullukla Mücadele Stratejileri, Ankara: Hak-İş Konfederasyonu Yayını.

Erdoğan, N.(2007). Yoksulluk Halleri: Türkiye'de Kent Yoksulluğunun Toplumsal Görünümleri. İletişim Yayınları, İstanbul.

Erman, T. (2004) 'Gecekondu Çalışmalarında 'Öteki' Olarak Gecekondulu Kurguları' European Journal of Turkish Studies, Thematic Issue 1 - Gecekondu, URL: http:/ / www.ejts.org/document85.html

Field, J. (2006). Sosyal Sermaye. İstanbul Bilgi Üniversitesi Yayınları, İstanbul.

Işık, O. ve Pınarcığlu, M. (2001). Nöbetleşe Yoksulluk: Sultanbeyli Örneği. İletişim Yayınları, İstanbul.

Jencks, C. ( 1996). “Can We Replace Welfare with Work?". Darby, M. R. (Ed). Reducing Poverty in America. ss. 69-81, Thousand Oaks, California, Sage.

Kalaycıoğlu, S. ve Rittersberger-Tilıç, H. (2001). Evlerimizdeki Gündelikçi Kadınlar: Cömert Ablaların Sadık Hanımları. Su Yayınları, İstanbul.

Kalaycıŏglu, S. ve Rittersberger-Tılıç, H. (2000). Intergenerational Solidarity Networks of Instrumental and Cultural Transfers within Migrant Families in Turkey". Aging and Society. Sayı:20, ss. 523-542.

Kalaycıoğlu, S. (2006) "Dynamics of poverty in Turkey: gender, rural/urban poverty, social Networks and reciprocal survival strategies" in Petmesidou M. \& Papatheodorou C, eds Poverty and Social Deprivation in the Mediterranean Area: Trends, Policies and Welfare Prospects in the New Millennium . London: Zed Books / CROP Series.pp. 218-247.

Kaşka, S., Gökçeoğlu-Balcı, Ş. ve Atılgan, S. (2004) Türkiye'de Sosyal Politika: Mevcut Kurumlar ve Politikalar, Yeni Eğilimler (www.spf.boun.edu.tr/docs/BU_SPF_Arastirma_Projesi-Sosyal_Politika_Surecleri.pdf).
Kıray, M. (1985), "Metropolitan City and the Changing Family", içinde T. Erder (der.) Family in Turkish Society, Ankara: Türkiye Sosyal Bilimler Derneği.

Kim, M. (1998). "Are the Working Poor Lazy?". Challenge. Cilt: 41, Sayı: 3, http://www.umb.edu/academics/cla/dept /economics/faculty/ documents/kim_are _wrking_poor_lazy.pdf (15.06.2008)

Lordoğlu, K. (2006). “Enformel İstihdam ve Türkiye Kaynakları", Toker Dereli'ye Armağan. Sosyal Politika, Çalışma Ekonomisi ve Endüstri İlişkileri Bilgi Portalı. http:/ / www.calisma.org/ (10.06.2009).

Molyneux, M. (2002). "Gender and the silences of social capital: lessons from Latin America". Development and Change. Cilt:33, Sayı:2, ss. $167-188$.

Munck, R. (2002). Emeğin Yeni Dünyası: Küresel Mücadele, Küresel Dayanışma. Kitap Yayınevi, İstanbul.

Murray, C. (1987). "In Search of the Working Poor". The Public Interest. Güz Sayısı, ss. 3-19.

Newman, K. S. (2000). No Shame in My Game: The Working Poor in the Inner City, Vintage Boks.

Özsoylu, A. F. (1994).“Kayıtdışı Ekonomiden Kim Kazanıyor? Kim Kaybediyor?". Ekonomik Forum Dergisi. Şubat Sayısı. TOBB Yayını, Ankara.

Özuğurlu, Aynur (2006) “Sosyal Sermaye: Kamunun Trajedisi Ya Da Emeğin Sömürgeleştirilmesinde Yeni Bir Eşik", Akdeniz Üniversitesi, İ.İ.B.F. Dergisi, 6(12), s.188-213.

Özyeğin, G. (2005). Başkalarının Kiri: Kapıcılar, Gündelikçiler ve Kadınlık Halleri. İletişim Yayınları, İstanbul.

Payne, S. (1991). Women, Health and Poverty. Harvester Wheadsheaf, London.

Pearce, D. (1978), "The Feminisation of Poverty: Women, Work and Welfare". The Urban and Social Change Review. Cilt: 11, Sayı: 1-2, ss. 28-36.

Putnam, R. D. (2000). Bowling Alone. Simon and Schuster, New York. 
Quigley, W. P. (2003). Ending Poverty As We Know It. Temple University Press, Philadelphia.

Øyen, E. (2002). “Social Capital Formation as a Poverty Reducing Strategy", in Social Capital and Poverty Reduction: Which Role For the civil society organizations and the state?, UNESCO, http:/ / unesdoc.unesco.org/images/0013/001325/132556e.pdf (9.9.2009).

Rea, J. (1996). "The Feminisation of Poverty: An International Perspective": Hughes, K.P. (Ed.). Contemporary Australian Feminism. Longman Chesire (2nd edition), Melbourne.

Ross, P. A. ve Gatta, M. L. (1999). "The Gender Gap in Earnings: Trends, Explanations, Prospects". İçinde: Powell, G.N. (Ed). Handbook of Gender and Work. Sage, California, ss. 95-123.

Ross, D., Scott, K. ve Smith, P. (2000). The Canadian Fact Book on Poverty 2000. Canadian Council on Social Development, Ottawa.

Sallan Gül, S. (2005). “Türkiye'de Yoksulluğun Kadınsılaşması". Amme İdaresi Dergisi. Cilt:38, Say1:1, ss. 25-43.

Schiller, B. (1994). "Who are the Working Poor?". The Public Interest. İlkbahar Sayısı, ss. 61-71.

Segal, E.A. (1991), “The Juvenilization of Poverty in the 1980s". Social Work. Cilt:36, Say1:5; ss. 454457.

Sen, A. K. (2004). Özgürlükle Kalkınma. Ayrıntı Yayınları, İstanbul.

Scott, C. (1994). "Theorizing Masculinities in Contemporary Social Science”, Brod, H. ve Kaufman, M. (Ed)., Theorizing Masculinities. Thousand Oaks, Sage, California.

Shipler, D. K. (2005). The Working Poor: Invisible in America. Vintage Books, New York.

Suğur, S. (2005). Türkiye'de Tekstil Sektöründe Kadın Emeği ve Değişen Toplumsal Cinsiyet İlişkileri". Amme İdaresi Dergisi. Cilt:38, Say1:1, ss. 47-68.

Şenses, F. (2001). Küreselleşmenin Öteki Yüzü: Yoksulluk. İletişim Yayınları, İstanbul.
Tobin, J. (1994). Poverty in Relation to Macroeconomic Trends, Cycles, Policies. İçinde: Danzinder, S. H.; Sandefur, G. D. ve Weinberg, D. H. (Ed.). Confronting Poverty: Prescriptinos for Change. Harvard University Press, Cambridge.

Toksöz, G., ve Özşuca, Ş. (2002). "Enformel Sektörde İstihdamın ve İşgücünün Özellikleri”. İktisat Dergisi. Sayı:430. http: / / acikarsiv.ankara.edu.tr/fulltext/339.htm, (24.06.2007).

TÜIK (2007). Hanehalkı Fertlerinin İşteki Durumuna Göre Yoksulluk Oranları. http: / / www.tuik.gov.tr/PreIstatistikTablo.do?istab_id=475 (15.10.2007).

ILO (2002). Decent Work and the Informal Economy: Abstracts of Working Papers. http:/ / www.ilo.org/public/english/employment /infeco/ download/abstract.pdf, (24. 06. 2007).

ILO (2007). Global Employment Trends. http://www..org/public/english /region/ampro/cinterfor/news/trends07.htm (09.11.2007).

UNDP (2005). Human Development Report 2005 Human Development Index. (http:/ / www.undp.org.tr/News_9sep05.asp ) (10.11.2007).

Wedel, H. (2001) Siyaset ve Cinsiyet: İstanbul Gecekondularında Kadınların Siyasal Katılımı, İstanbul, Metis.

Woolcock, M. (2002), "Social Capital in Theory and Practice: Reducing Poverty by Building Partnerships between states, Markets and civil society", in Social Capital and Poverty Reduction: Which Role For the civil society organizations and the state, UNESCO, http: / / unesdoc.unesco.org / images/0013/001325/132556e.pdf (9.9.2009).

World Bank, (2000). World Development Report, 2000/2001: Attacking Poverty. World Bank, Washington.

World Bank (2007). PovertyNet. http:/ / go.worldbank.org/33CTPSVDC0 (12.11.2007). 